\title{
Biochemical and physiological bases for the use of carbon and nitrogen isotopes in environmental and ecological studies
}

\author{
Naohiko Ohkouchi ${ }^{1 *}$, Nanako O Ogawa ${ }^{1}$, Yoshito Chikaraishi ${ }^{1}$, Hiroyuki Tanaka ${ }^{2}$ and Eitaro Wada ${ }^{1,3}$
}

\begin{abstract}
We review the biochemical and physiological bases of the use of carbon and nitrogen isotopic compositions as an approach for environmental and ecological studies. Biochemical processes commonly observed in the biosphere, including the decarboxylation and deamination of amino acids, are the key factors in this isotopic approach. The principles drawn from the isotopic distributions disentangle the complex dynamics of the biosphere and allow the interactions between the geosphere and biosphere to be analyzed in detail. We also summarize two recently examined topics with new datasets: the isotopic compositions of individual biosynthetic products (chlorophylls and amino acids) and those of animal organs for further pursuing the basis of the methodology. As a tool for investigating complex systems, compound-specific isotopic analysis compensates the intrinsic disadvantages of bulk isotopic signatures. Chlorophylls provide information about the particular processes of various photoautotrophs, whereas amino acids provide a precise measure of the trophic positions of heterotrophs. The isotopic distributions of carbon and nitrogen in a single organism as well as in the whole biosphere are strongly regulated, so that their major components such as amino acids are coordinated appropriately rather than controlled separately.
\end{abstract}

Keywords: Carbon isotopic composition; Nitrogen isotopic composition; Ecosystem; Food web; Chlorophyll; Trophic position; Amino acid; Animal organ

\section{Review}

\section{Introduction}

The biological processes that significantly affect the Earth's surface environment generally lack rigorous formulations because they are intrinsically elastic. However, using the chemical signatures induced by molecular motion (vibrational, translational, and rotational), we can at least document them rigorously and accurately. In recent decades, the natural abundances of stable carbon and nitrogen isotopes (represented as ${ }^{13} \mathrm{C} /{ }^{12} \mathrm{C}$ and ${ }^{15} \mathrm{~N} /{ }^{14} \mathrm{~N}$ ratios, respectively) have been widely used to probe biogeochemical and ecological processes. Thanks in part to such isotopic evidence, we have come to understand our living planet more clearly. Carbon and nitrogen are essential elemental constituents of organisms and form various chemical species

\footnotetext{
* Correspondence: nohkouchi@jamstec.go.jp

'Japan Agency for Marine-Earth Science and Technology, 2-15

Natsushima-cho, Yokosuka 237-0061, Japan

Full list of author information is available at the end of the article
}

on Earth. The isotopic compositions of these elements provide process-related and source information.

Historically, this field started as early as the 1930s, when a custom-made mass spectrometer was constructed to measure subtle differences in the isotopic ratios of natural carbon (Nier and Gulbransen 1939). Although the carbon and nitrogen isotopic compositions of diverse types of organic matter were measured and discussed by the pioneers of isotope geochemistry (e.g., Rankama 1948; Wickman 1952; Craig 1953; Hoering 1955; Parwel et al. 1957), the isotopic fractionation associated with various biochemical reactions was only determined precisely after some time (e.g., Park and Epstein 1960; DeNiro and Epstein 1977; Hoering and Ford 1960; Wada 1980). As our knowledge of the distributions of carbon and nitrogen isotopes in organic matter and the factors controlling them has accumulated, the scope of isotopic measurements has greatly expanded.

An important application of the analysis of carbon and nitrogen isotopic compositions is in ecological studies. 
In 1967, Y. Miyake and E. Wada first reported that marine animals incorporate dietary ${ }^{15} \mathrm{~N}$ in preference to ${ }^{14} \mathrm{~N}$ (Miyake and Wada 1967). Later, several seminal papers provided robust data on the ${ }^{15} \mathrm{~N}$-enrichment that occurs during heterotrophic processes, based on diet-controlled laboratory culture experiments (e.g., DeNiro and Epstein 1981; Minagawa and Wada 1984). This ${ }^{15} \mathrm{~N}$-enrichment is a reflection of biochemical processes that accompany significant isotopic fractionation. The carbon isotopic composition of an organism mainly reflects its dietary signature (DeNiro and Epstein 1978), and coordinated isotopic measurements of organisms provide a unique approach to describing the dietary habits of animals, a macroscale ecological phenomenon. Such macroscale functions in the biosphere strongly influence the Earth's surface environment via the population dynamics of ecosystems (Begon et al. 2006). In this review, we summarize our current knowledge on the theoretical background underlying this approach. To achieve this, we consider the processes sequentially, first describing the isotopic relationships between substrates and autotrophs. We also present original datasets to address two related topics, compound-specific and organ-level isotopic compositions, which are helpful in achieving this goal.

\section{Isotopes and isotopic fractionation}

In nature, organic matter contains substantial amounts of stable isotopes of the 'light elements', including hydrogen, carbon, and nitrogen. For example, a human body weighing $50 \mathrm{~kg}$ contains over $200 \mathrm{~g}$ of the heavier isotopes of these elements (Wada et al. 1995). Small variations in the isotopic compositions present in nature are generally described by comparing the ratios of the isotopes in the sample material with those of standard (or reference) materials. These are expressed in the conventional $\delta$ notation defined below:

$$
\delta(\%) \equiv 10^{3}\left(R_{\text {sample }} / R_{\text {standard }}-1\right)
$$

where the term $R$ denotes the ${ }^{13} \mathrm{C} /{ }^{12} \mathrm{C}$ ratio for carbon or the ${ }^{15} \mathrm{~N} /{ }^{14} \mathrm{~N}$ ratio for nitrogen. In general, Vienna Pee Dee belemnite (VPDB; ${ }^{13} \mathrm{C} /{ }^{12} \mathrm{C} \simeq 0.011179$; Coplen et al. 2002) and atmospheric nitrogen (AIR; ${ }^{15} \mathrm{~N} /{ }^{14} \mathrm{~N} \simeq 0.003677$; Junk and Svec 1958) are used as the standards for carbon and nitrogen, respectively. Because authentic standards such as NBS-19 are not largely available, the reference materials routinely used are prepared in each laboratory or community (e.g., Tayasu et al. 2011). When a sample contains less ${ }^{13} \mathrm{C}$ or ${ }^{15} \mathrm{~N}$ than the standard, the $\delta$ value is negative. A $\delta$ value of $-20 \%$ indicates that the isotopic ratio of the sample is $2 \%$ lower than that of the standard (in the case of carbon, ${ }^{13} \mathrm{C} /{ }^{12} \mathrm{C} \simeq 0.01096$ ).

All physicochemical processes cause isotopic fractionation, which can be observed by measuring the isotopic compositions of both the reactants and products. The magnitude of isotopic fractionation is described as either the 'isotopic fractionation factor' denoted by $\alpha$, or the 'isotopic fractionation' denoted by $\varepsilon$, defined with the following equations:

$$
\begin{aligned}
& \alpha_{r / p} \equiv R_{r} / R_{p} \\
& \varepsilon_{r / p} \equiv 10^{3}\left(R_{r} / R_{p}-1\right)=10^{3}\left(\alpha_{r / p}-1\right)
\end{aligned}
$$

where the subscripts $r$ and $p$ designate the reactant and product of a reaction, respectively. The $\varepsilon_{r / p}$ values for enzymatic reactions are generally positive for both carbon and nitrogen.

There are two types of isotope effects: isotope (exchange) equilibrium and the kinetic isotope effect. Isotope equilibrium is observed in a closed, mixed system in which a bidirectional reaction occurs and chemical equilibrium is attained. A typical example of isotope equilibrium can be seen between gaseous $\mathrm{CO}_{2}$ and dissolved bicarbonate $\left(\mathrm{HCO}_{3}{ }^{-}\right)$:

$$
{ }^{13} \mathrm{CO}_{2(\text { gas })}+\mathrm{H}^{12} \mathrm{CO}_{3}{ }^{-} \rightleftharpoons{ }^{12} \mathrm{CO}_{2(\text { gas })}+\mathrm{H}^{13} \mathrm{CO}_{3}{ }^{-}
$$

In this case, the isotope effect occurs during the formation and destruction of the bonds involving a carbon atom. In this reaction, the equilibrium constant $K$ is expressed as follows:

$$
\begin{aligned}
& K=\left(\left[{ }^{12} \mathrm{CO}_{2(\text { gas })}\right]\left[\mathrm{H}^{13} \mathrm{CO}_{3}\right]\right) /\left(\left[{ }^{13} \mathrm{CO}_{2(\text { gas })}\right]\left[\mathrm{H}^{12} \mathrm{CO}_{3}{ }^{-}\right]\right) \\
& =\left({ }^{13} \mathrm{C} /{ }^{12} \mathrm{C}\right)_{\mathrm{HCO}_{3}{ }^{-}} /\left({ }^{13} \mathrm{C} /{ }^{12} \mathrm{C}\right)_{\mathrm{CO}_{2(\text { gas })}} \\
& =\alpha_{\mathrm{HCO}_{3}{ }^{-} / \mathrm{CO}_{2 \text { (gas) }}}
\end{aligned}
$$

In an exchange reaction containing only one exchangeable atom, the equilibrium constant $K$ is equivalent to the isotopic fractionation factor $\alpha$. At a water temperature of

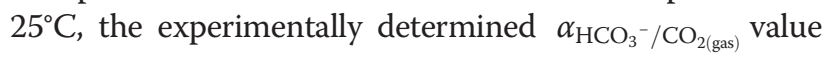
for the above reaction is 1.0079 (Mook et al. 1974). It indicates that at equilibrium, the carbon isotopic composition of $\mathrm{CO}_{2}$ in the atmosphere is $-7.9 \%$ when that of $\mathrm{HCO}_{3}^{-}$ in the surface water is $0.0 \%$. Most of this fractionation occurs in the hydration stage $\left(\mathrm{CO}_{2(\mathrm{aq})}+\mathrm{H}_{2} \mathrm{O} \rightleftharpoons \mathrm{H}_{2} \mathrm{CO}_{3}\right)$ and not during the exchange across the air-water interface $\left(\mathrm{CO}_{2 \text { (gas) }} \rightleftharpoons \mathrm{CO}_{2(\mathrm{aq})}\right)$ or in the dissociation of carbonic acid $\left(\mathrm{H}_{2} \mathrm{CO}_{3} \rightleftharpoons \mathrm{HCO}_{3}^{-}+\mathrm{H}^{+}\right)$.

Although the isotopes of a particular element have rather similar chemical behaviors, their specific thermodynamic parameters and rate constants in chemical and biological reactions differ. The kinetic isotope effect is considered to best describe the isotopic fractionation that occurs in the metabolic processes within a cell. The kinetic isotope effect is observed in irreversible or unidirectional reactions, such as evaporation, diffusion, and 
biologically mediated reactions. In such reactions, the isotopic compositions of the reactant $\left(\delta_{r}\right)$ and the cumulative product $\left(\delta_{p}\right)$ are conventionally described with the following equations:

$$
\begin{aligned}
& \delta_{r}=\delta_{0}-\varepsilon_{r / p} \ln f \\
& \delta_{p}=\delta_{0}+f /(1-f) \varepsilon_{r / p} \ln f
\end{aligned}
$$

where $f(0 \leq f \leq 1)$ is the fraction of unutilized substrate remaining and $\delta_{0}$ is the isotopic composition when $f=0$. It should be noted that these equations are approximate forms of the Rayleigh distillation model, and the error expands as $f$ decreases. Figure 1 is a schematic representation of the isotopic compositions of the reactant(s) and product(s) in such a unidirectional reaction in a closed system.

In general, the rate constant for the light molecule (the molecule containing the light isotope), which has higher vibrational zero-point energy, is greater than that for the heavy molecule (the molecule containing the heavy isotope) (Bigeleisen 1949). Therefore, the product

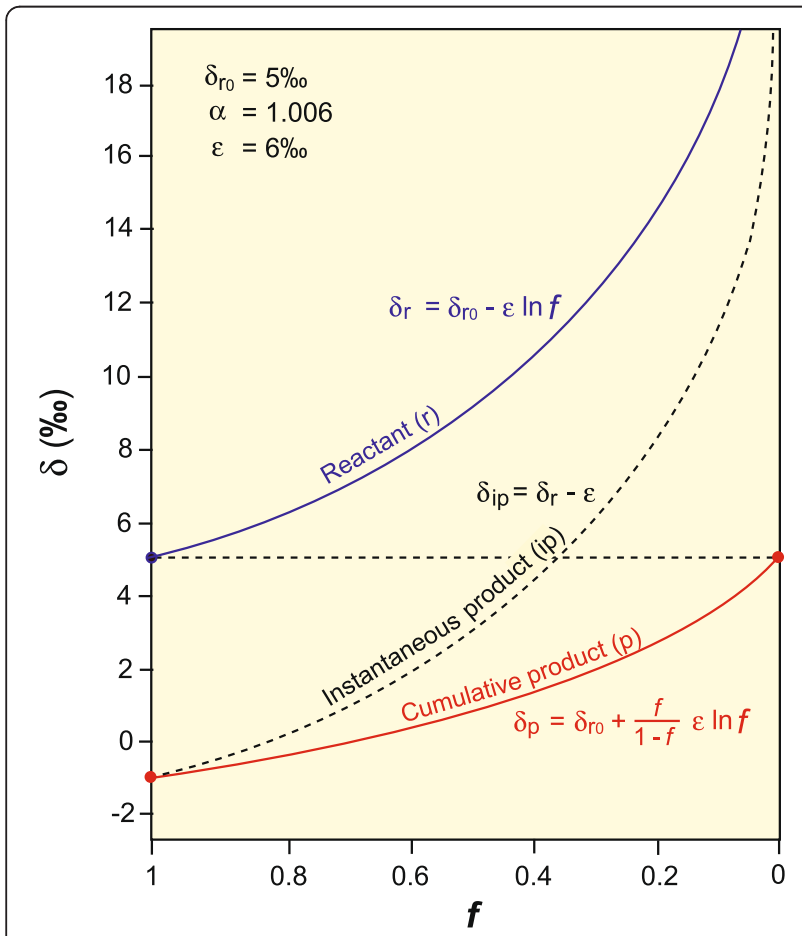

Figure $1 \mathrm{~A}$ schematic diagram showing the kinetic isotope effect. The isotopic compositions of unconsumed reactant (blue, solid line), instantaneous product (black, broken line), and cumulative product (red, solid line) are shown as a function of the fraction of unutilized substrate $(f)$ for a unidirectional reaction. Mathematical formulae for these reactants and products are also shown. Subscripts $r$, ip, and $p$ represent reactant, instantaneous product, and accumulated product, respectively. Modified from Mariotti et al. (1981). of the reaction is depleted in heavy isotope $\left({ }^{13} \mathrm{C}\right.$ or $\left.{ }^{15} \mathrm{~N}\right)$ relative to the reactant $\left(\alpha_{r / p}>1\right.$ and $\left.\varepsilon_{r / p}>0\right)$. The magnitude of the isotopic fractionation depends on various factors, but in biochemical reactions, it is strongly related to the inherent characteristics of the enzyme catalyzing the reaction. The assimilation of $\mathrm{CO}_{2}$ and nitrate by autotrophs exemplifies reactions of this kind, which will be discussed in the following "Carbon and nitrogen isotopic compositions of autotrophs: isotopic changes during anabolism" section.

\section{Carbon and nitrogen isotopic compositions of autotrophs: isotopic changes during anabolism}

Both the carbon and nitrogen that form autotrophic cells are originally derived from inorganic substrates, such as environmental $\mathrm{CO}_{2}$ and nitrate, respectively (Figure 2). In addition to $\mathrm{CO}_{2}$, methane $\left(\mathrm{CH}_{4}\right)$, acetate $\left(\mathrm{CH}_{3} \mathrm{COOH}\right)$, amino acids, and other small carbon compounds are also used as carbon substrates by some specific autotrophs. Although we still do not know the quantitative importance of these substrates or the 'recycling' of organic matter in nature (Takano et al. 2010), here we assume that $\mathrm{CO}_{2}$ is the overwhelmingly important substrate in both terrestrial and aquatic environments. The situation is more complicated for nitrogen. Although nitrate $\left(\mathrm{NO}_{3}{ }^{-}\right)$and ammonium $\left(\mathrm{NH}_{4}^{+}\right)$are often considered to be the substrates of autotrophic processes, dinitrogen $\left(\mathrm{N}_{2}\right)$, nitrite $\left(\mathrm{NO}_{2}{ }^{-}\right)$, urea $\left(\mathrm{NH}_{2} \mathrm{CONH}_{2}\right)$, and some amino acids are also used as substrates by some autotrophs. For simplicity, we will mainly treat $\mathrm{CO}_{2}$ and nitrate as the carbon and nitrogen substrates, respectively, in the discussion below.

When $\mathrm{CO}_{2}$ is assimilated by an aquatic alga, it diffuses across the plasma membrane from the environment to the intracellular $\mathrm{CO}_{2}$ pool, which is followed by carboxylation catalyzed by ribulose bisphosphate carboxylase/oxygenase (RubisCO). In contrast, nitrate is actively transported across the membrane to the intracellular nitrate pool, where it is subjected to sequential enzymatic reduction to nitrite and ammonium used in the synthesis of amino acids (summarized by Ohkouchi and Takano 2014). In both cases, isotopic fractionation occurs during the transport of the substrate across the plasma membrane and the enzymatic fixation of the substrate in the cell. The isotopic fractionation associated with the assimilations of $\mathrm{CO}_{2}$ and nitrate by photoautotrophs has been successfully explained with a two-step model (Figure 2a,b; Park and Epstein 1960; Wada and Hattori 1978; O'Leary 1981; Farquhar et al. 1982; Hayes 1991). In this model, the diffusional process across the membrane is reversible, whereas enzymatic fixation is irreversible. The overall kinetic isotope fractionation $\varepsilon_{p}$ is expressed with several types of formulae (e.g., Wada and Hattori 1978; Farquhar 1983; Hayes 1991; Chikaraishi 2014). 


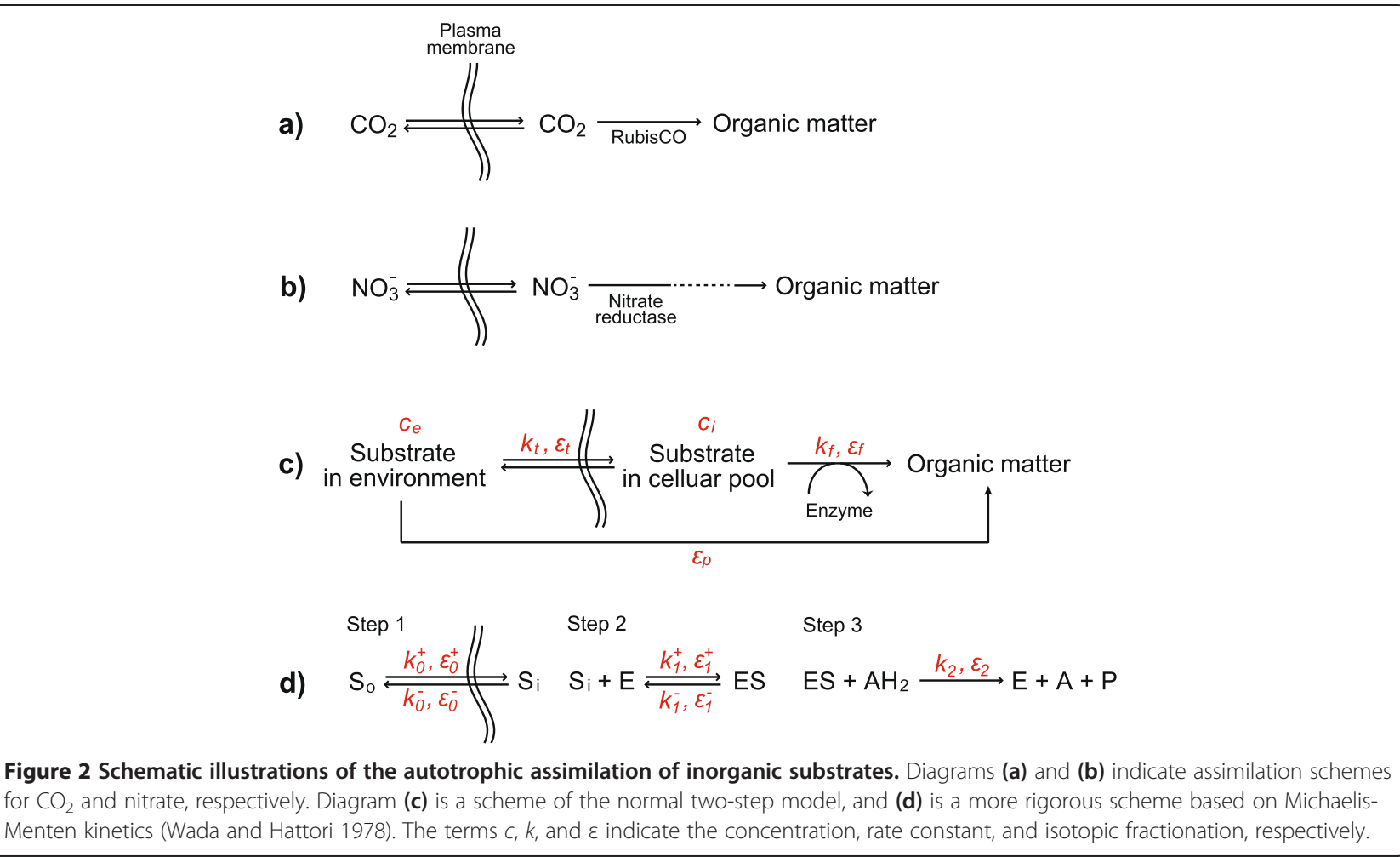

The equation often seen in the literature is related to the substrate concentrations outside and inside the cell (specified as $c_{e}$ and $c_{i}$, respectively).

$$
\varepsilon_{p}=\varepsilon_{t}+\left(\varepsilon_{f}-\varepsilon_{t}\right) c_{i} / c_{e}
$$

where $\varepsilon_{t}$ is the isotopic fractionation associated with the diffusion or active transport of the substrate across the plasma membrane, and $\varepsilon_{f}$ is the net fractionation caused by the enzymatic reaction that fixes the substrate (carboxylation or nitrate reduction; see Figure 2c). The values of $\varepsilon_{t}$ during $\mathrm{CO}_{2}$ assimilation were determined experimentally to be $2.9 \%$ o to $4.4 \%$ o for terrestrial plants (Craig 1957; Farquhar 1983) and $0.7 \%$ o to $0.9 \%$ for aquatic plants (O'Leary 1984; Jähne et al. 1987). In contrast, the value of $\varepsilon_{f}$ is far greater than that of $\varepsilon_{t}$, ranging from $18 \%$ o to $30 \%$, which was estimated with pure RubisCO isolated from various plants and assayed under physiological conditions (summarized by Chikaraishi 2014). The equation given above has been applied when reconstructing the $\mathrm{CO}_{2}$ concentrations in water or the atmosphere in the geological past (e.g., Pagani et al. 2005).

It must be remembered that $\varepsilon_{p}$ is not only controlled by $c_{e}$ but also by other factors. In particular, in low- $\mathrm{CO}_{2}$ environments such as the present atmosphere, the growth rates of autotrophs have been shown to strongly control $\varepsilon_{p}$. The equation below was developed by
Takahashi et al. (1991) to explain the $\mathrm{CO}_{2}$ assimilation by the freshwater green alga Chlamydomonas reinhardtii:

$$
\varepsilon_{p}=\varepsilon_{f}+\left(\varepsilon_{t}-\varepsilon_{f}\right) k_{f} / k_{t}
$$

where $k_{t}$ and $k_{f}$ are the rate constants for the transport of the substrate across the membrane and from the intracellular pool to the organic matter, respectively (Figure 2c). Because $0 \leq k_{f} / k_{t} \leq 1$, the value of $\varepsilon_{p}$ is expected to vary between $\varepsilon_{t}$ and $\varepsilon_{f}$. Because $\varepsilon_{t}$ is much smaller than $\varepsilon_{f}$, it is clear that the overall isotopic fractionation $\left(\varepsilon_{p}\right)$ correlates negatively with the growth rate $\left(k_{f}\right)$, which is controlled by environmental factors such as light intensity and substrate supply. When the growth rate increases, the mass transport tends to be a rate-limiting step. This relationship was clearly observed in laboratory culture experiments of not only C. reinhardtii (Figure 3a; Takahashi et al. 1991) but also the cyanobacterium Agmenellum quandruplicatum (Wada et al. 2012).

In contrast, Wada and Hattori (1978) derived a more rigorous formula based on Michaelis-Menten kinetics to explain the nitrogen isotopic fractionation that occurs during nitrate assimilation by the marine diatom Phaeodactylum tricornutum (Figure 2d):

$$
\begin{aligned}
& \varepsilon_{p}=\varepsilon_{0}{ }^{+}+\varepsilon_{2} X Y-\varepsilon_{0}{ }^{-} X \\
& \left(X=1-k_{2}[E S] / k_{0}{ }^{+}\left[S_{0}\right], Y=k_{1}{ }^{-} /\left(k_{1}{ }^{-}+k_{2}\right)\right)
\end{aligned}
$$



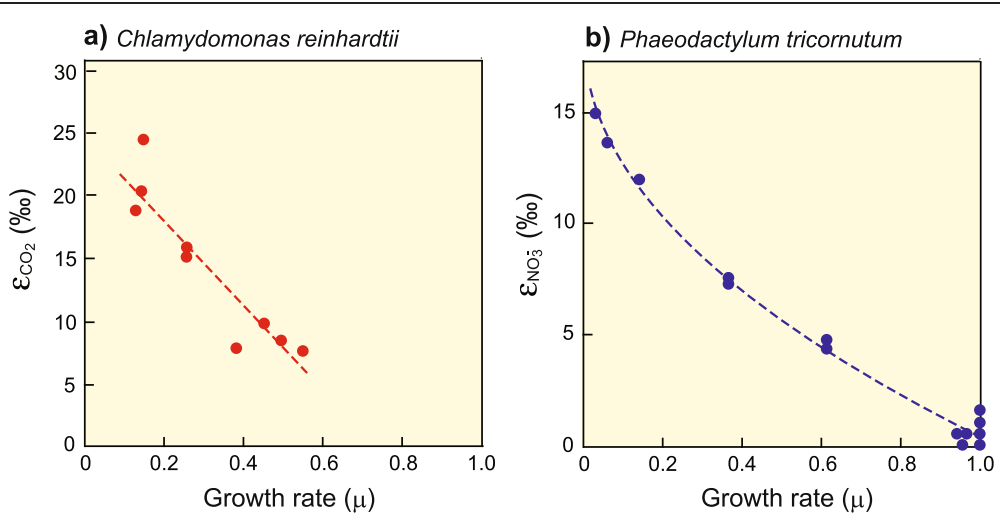

Figure 3 Experimental results indicating the relationship between isotopic fractionation and growth rate $(\mu)$ of an alga. Variations in (a) the carbon isotopic fractionation associated with $\mathrm{CO}_{2}$ assimilation $\left(\varepsilon_{\mathrm{CO}_{2}}\right)$ by the freshwater green alga Chlamydomonas reinhardtii (modified from Takahashi et al. 1991) and (b) the nitrogen isotopic fractionation associated with nitrate assimilation $\left(\varepsilon_{\mathrm{NO}_{3}}\right)$ by the marine diatom Phaeodactylum tricornutum (modified from Wada and Hattori 1978).

where subscripts 0,1 , and 2 represent the sequential reactions from substrate transport across the membrane to the formation of organic matter (Figure 2d), and the superscripts + and - represent the forward and backward reactions, respectively. In this equation, the overall isotopic fractionation $\left(\varepsilon_{p}\right)$ correlates negatively but not linearly with the growth rate $\left(k_{2}\right)$ (Figure $3 \mathrm{~b}$ ).

In natural environments, the isotopic compositions of photoautotrophs occur across wide ranges: from $-38 \%$ to $-10 \%$ for carbon (Figure $4 \mathrm{a}$ ) and from $-9 \%$ to $+10 \%$ o for nitrogen (Figure $4 \mathrm{~b}$ ). The approximately $10 \%$ depletion of ${ }^{13} \mathrm{C}$ in terrestrial plants relative to that in aquatic plants may be explained by the fast diffusion of $\mathrm{CO}_{2}$ in air relative to that in water. These wide ranges are partially ascribed to fluctuations in the isotopic compositions of the substrates in the aquatic and terrestrial environments. For example, in a modern cultivated field, nitrogen is heavily supplied as chemically synthesized fertilizers whose $\delta^{15} \mathrm{~N}$ values generally range from $-6 \%$ to $+7 \%$ o (Heaton 1986; Vitòria et al. 2004). Therefore, fertilizer significantly overwrites the isotopic signature of the nitrogen substrate in the soil. The processes and dynamics of substrate assimilation also affect the isotopic compositions of biosynthetic products (Hayes 1991; Fogel and Cifuentes 1993; Raven 1997; Chikaraishi 2014; Ohkouchi and Takano 2014). A well-known example is the carbon isotopic compositions of $\mathrm{C}_{3}$ and $\mathrm{C}_{4}$ plants. The former assimilate $\mathrm{CO}_{2}$ simply via RubisCO, whereas the latter assimilate $\mathrm{CO}_{2}$ through phosphoenolpyruvate carboxylase (PEPC) after $\mathrm{CO}_{2}$ is concentrated in the cell as a form of phosphoenolpyruvate. Because most $\mathrm{CO}_{2}$ transported into the $\mathrm{C}_{4}$ plant cell is used for the synthesis of organic matter, the carbon isotopic composition of $\mathrm{C}_{4}$ plants is relatively close to that of the substrate (atmospheric $\mathrm{CO}_{2}$ ) (Figure 4a). In all cases, the substrate assimilation processes are controlled by Rayleigh-distillation- type kinetics, and the isotopic composition of the product is not constant but intrinsically variable.

During nitrate assimilation, the isotopic fractionation of the enzymatic reaction catalyzed by nitrate reductase ranges from $2 \%$ to $10 \%$ (summarized by Ohkouchi and Takano 2014). Because the nitrate concentration in the pelagic ocean is generally up to several micromolar (approximately 3 orders of magnitude lower than the concentration of dissolved $\mathrm{CO}_{2}$ ) except at high latitudes, nitrate is actively transported into the cell (Falkowski 1975). This may cause little isotopic fractionation during the transport of nitrate into the cell. Dissolved $\mathrm{N}_{2}$ is slightly enriched in ${ }^{15} \mathrm{~N}$ relative to that in the atmosphere (Figure $4 \mathrm{~b}$ ), reflecting the slight isotopic fractionation associated with the equilibration of $\mathrm{N}_{2}$ between the gaseous and aqueous phases $\left(\varepsilon_{\mathrm{N}_{2(\text { aq }} / \mathrm{N}_{2(\text { gas }}} \simeq 0.7 \%\right.$ at $25^{\circ} \mathrm{C}$; Klots and Benson 1963). Except for regions where $\mathrm{N}_{2}$-fixation and denitrification are dominant, the nitrogen isotopic composition of oceanic nitrate usually ranges from $5 \%$ to $10 \%$. The nitrogen isotopic composition of nitrate from the surface photic zone is generally greater than $5 \%$ the mean value for oceanic nitrate (Sigman et al. 2009) because of the biological uptake of nitrate. When nitrogen is supplied via biological $\mathrm{N}_{2}$ fixation, the bulk cells display a narrow $\delta^{15} \mathrm{~N}$ range, predominantly between $-2 \%$ and $0 \%$ (Figure $4 \mathrm{~b}$; Hoering and Ford 1960; Minagawa and Wada 1986). The small isotopic fractionation associated with this process suggests that the cleavage of the strong triple bond of $\mathrm{N}_{2}$ takes place under irreversible conditions (Wada et al. 2012) with high utilization (i.e., $f \simeq 0$; Figure 1 ) of the $\mathrm{N}_{2}$ incorporated into the cell. In aquatic environments, most cyanobacteria and photosynthetic bacteria have an ability to conduct $\mathrm{N}_{2}$-fixation, and in the terrestrial environment, some plants such as legumes contain symbiotic bacteria that fix $\mathrm{N}_{2}$ in their root nodules. In contrast, 


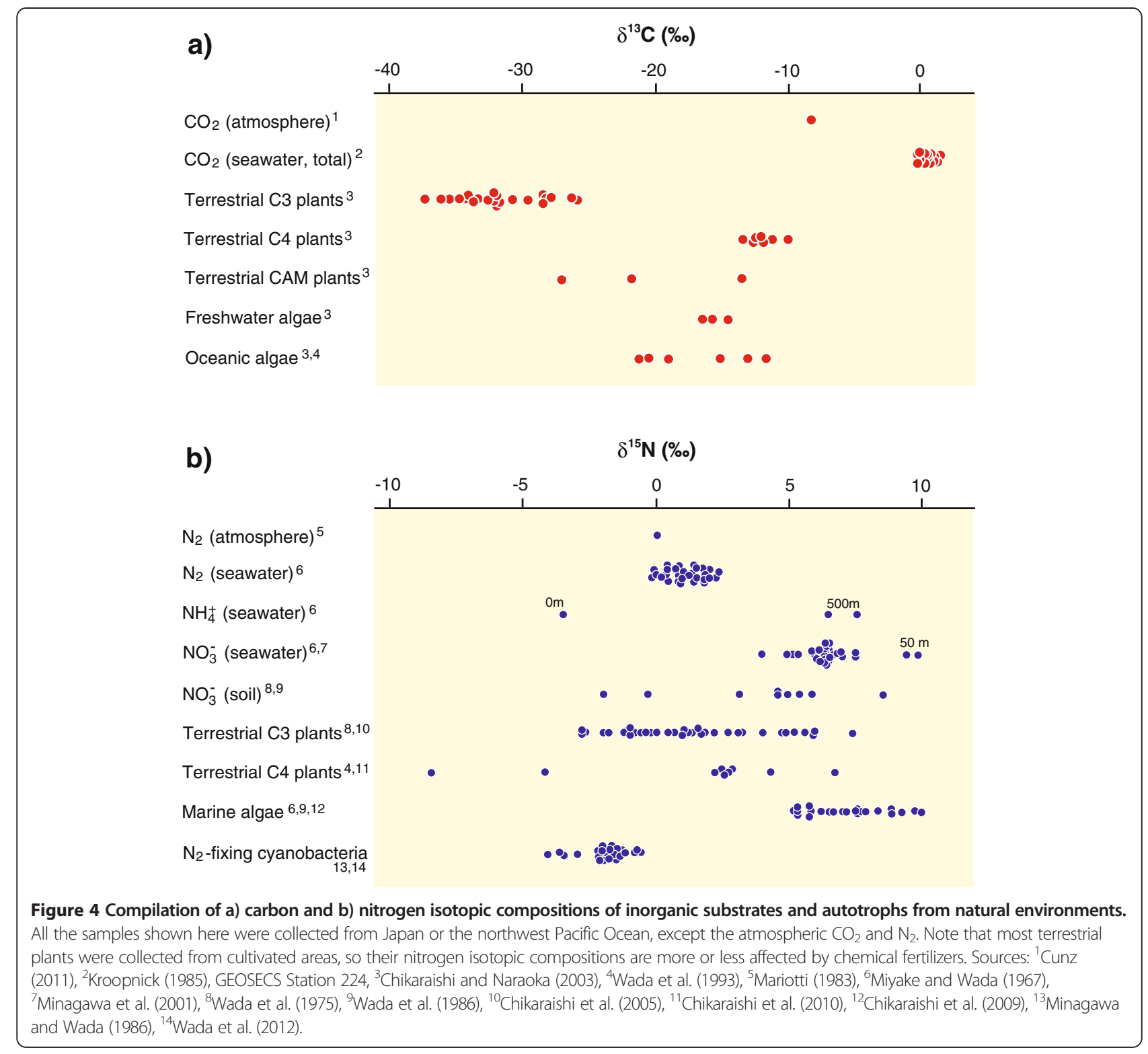

when nitrogen is abundantly supplied to the soil via precipitation as nitrate, the isotopic signatures of plants are generally consistent with that of the nitrate.

Figure 5 summarizes the $\delta^{13} \mathrm{C}$ and $\delta^{15} \mathrm{~N}$ values for autotrophs from various environments, many of which have been investigated by one of the authors (EW) over 40 years of his career. In natural environments, the isotopic compositions of autotrophs range widely, depending upon the substrate, the assimilation process, and the substrate utilization. To our knowledge, an algal felt from a penguin rookery in Antarctica displayed the highest autotrophic $\delta^{15} \mathrm{~N}$ value (approximately $+31 \%$ ), which was attributed to the evaporation of ammonia from the soil, whereas the lowest value $(-49 \%)$ was observed in algae collected from a pond in the Dry Valley area in Antarctica (Wada et al. 1981). Such ${ }^{15} \mathrm{~N}$-depletion is probably attributable to the large isotopic fractionation during assimilation with a slow growth rate and the elevated nitrate concentration in the pond. In methane seeps, some archaea and bacteria assimilate methane, causing strong ${ }^{13} \mathrm{C}$-depletion in the cellular components (approximately $-130 \%$; e.g., Hinrichs et al. 1999). The biochemical processes related to the ${ }^{13} \mathrm{C}$-depletion in these microorganisms are not well understood.

In aquatic environments, it is technically difficult to rigorously separate autotrophs (i.e., algae and cyanobacteria) from heterotrophs and detritus. Consequently, the carbon and nitrogen isotopic compositions of particulate organic matter (POM) have long been substituted for those of photoautotrophs in surface water. However, 


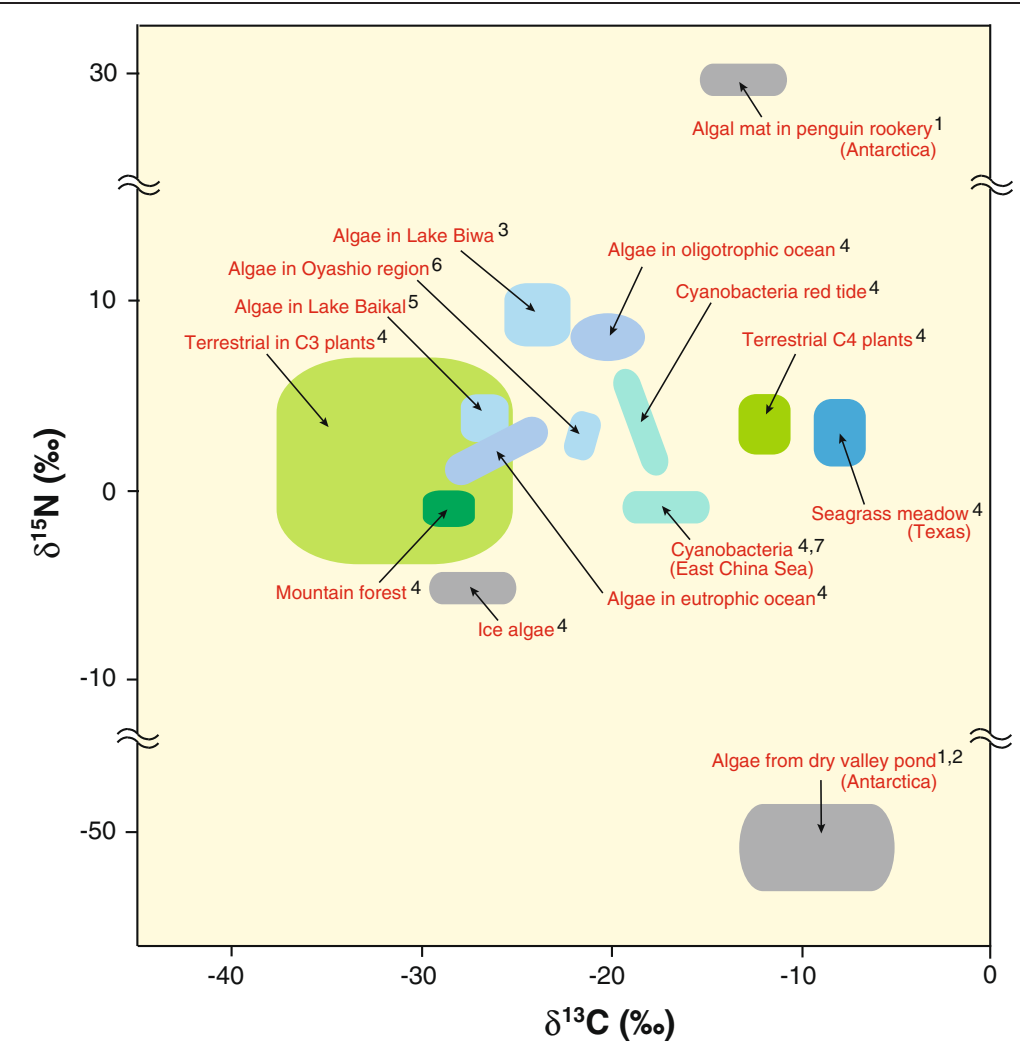

Figure 5 Summary of the $\delta^{13} \mathrm{C}$ and $\delta^{15} \mathrm{~N}$ values for autotrophs from various environments. Superscripts indicate the sources: ${ }^{1}$ Wada et al. (1981), ${ }^{2}$ Wada et al. (2012), ${ }^{3}$ Yamada et al. (1998), "Wada and Hattori (1991), ${ }^{5}$ Yoshii et al. (1999), ${ }^{6}$ Aita et al. (2011), ${ }^{7}$ Minagawa and Wada (1986)".

these records must be more or less overprinted by the isotopic signatures of the detritus from other organisms. Therefore, the isotopic compositions of chlorophylls are useful for more accurately characterizing the isotopic signatures of primary photosynthates. Chlorophylls are abundantly produced only by photoautotrophs and contain four nitrogen atoms. The biochemical processes of chlorophyll synthesis in the photoautotrophic cell have been studied intensively (e.g., Beale 1995). This strong research background is an advantage when interpreting the isotopic signatures of chlorophylls (Katase and Wada 1990; Ohkouchi et al. 2006, 2008), although the number of applications of this technique is still limited.

This approach is particularly useful for understanding complex ecosystems. Lake Kaiike is a meromictic lake located on the coast of Kamikoshiki Island, southwest Japan. Because of its locality, seawater leaks into the deeper part of the lake through a gravel bar. In contrast, the surface water of the lake is covered by freshwater flowing from the watershed. Therefore, the lake is permanently stratified with a strong density gradient, generating an anaerobic water body below the chemocline at a depth of around $5 \mathrm{~m}$. Figure 6 illustrates both the carbon and nitrogen isotopic compositions of three types of chloropigments isolated from the water column of the lake, chlorophyll $a$, bacteriochlorophyll $a$, and bacteriochlorophylls $e$ (Nakajima et al. 2004). In this lake, these chloropigments were derived from cyanobacteria, purple sulfur bacteria, and brown-colored green sulfur bacteria, respectively. The three types of chloropigments have unique isotopic signatures, attributable to the distinctive ecologies and physiologies of these photoautotrophs. At the redox boundary of the water column, bacteriochlorophylls $e$ are nearly $10 \%$ depleted in ${ }^{13} \mathrm{C}$ relative to bacteriochlorophyll $a$, even though both the green and purple sulfur bacteria assimilate $\mathrm{CO}_{2}$ (Figure 6a; Ohkouchi et al. 2005). This large variation in ${ }^{13} \mathrm{C}$ is ascribed to the different assimilation pathways used by these photoautotrophs in synthesizing these pigments: purple sulfur bacteria fix $\mathrm{CO}_{2}$ via the $\mathrm{C}_{3}$ carboxylation pathway catalyzed by RubisCO, whereas green sulfur bacteria use the reverse tricarboxylic acid cycle catalyzed by $\alpha$-ketoglutarate synthase. The latter process fractionates ${ }^{13} \mathrm{C}$ far less than the former process (Sirevåg et al. 1977; Quandt et al. 1977). Bacteriochlorophylls $e$ are far more depleted in ${ }^{15} \mathrm{~N}$ relative to either chlorophyll $a$ or bacteriochlorophyll $a$ (Figure 6b). This suggests that the green sulfur bacteria either fix $\mathrm{N}_{2}$ or grow very slowly by assimilating ammonium. In the aquatic environment where various processes occur simultaneously, compound-specific isotope analysis 

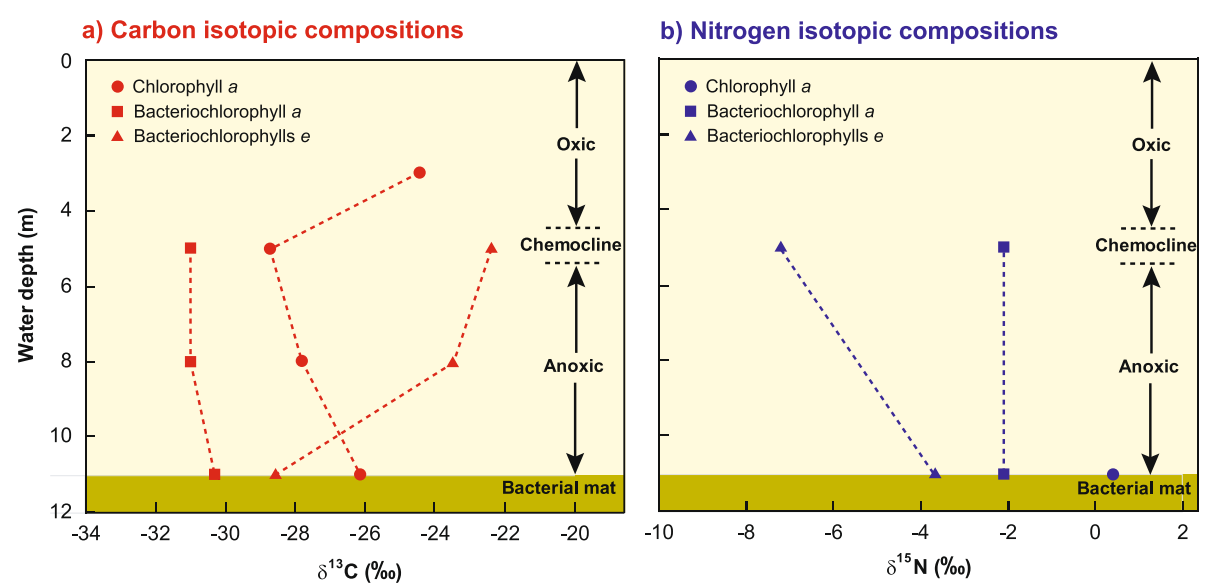

Figure 6 Carbon and nitrogen isotopic compositions of three types of chloropigments from Lake Kaiike, Japan. Carbon (a) and nitrogen (b) isotopic compositions of chloropigments (i.e., chlorophyll $a$, bacteriochlorophyll $a$, and bacteriochlorophylls e) from the water column of meromictic Lake Kaiike, Japan. The water column of the lake is strongly stratified with a chemocline at a depth of around $5 \mathrm{~m}$. Below the chemocline, oxygen is depleted but hydrogen sulfide is abundant. The isotopic compositions of bacteriochlorophylls $e$ are the mean values for those of bacteriochlorophylls $e_{1}, e_{2}$, and $e_{3}$. Redrawn from Ohkouchi et al. (2005).

is a useful tool for disentangling multiple coexisting signals. However, it must be kept in mind that isotopic discrimination occurs during chlorophyll biosynthesis, which produces substantial isotopic differences between the chlorophylls and the whole algal cells (chlorophylls are approximately $0.5 \%$ depleted in ${ }^{13} \mathrm{C}$ and approximately $5 \%$ depleted in ${ }^{15} \mathrm{~N}$ relative to the cell; Hayes et al. 1989; Sachs et al. 1999; Ohkouchi et al. 2006). Nevertheless, the interpretation of the isotopic records of complex ecosystems can advance by separating processes, which is made possible by compound-specific isotope analyses.

\section{Food chain analysis with bulk isotopic compositions: isotopic changes during catabolism}

Once produced by autotrophs, organic matter is utilized by heterotrophs as an energy source. The heterotrophic processes generally involve breaking down organic matter to smaller compounds. In these catabolic processes, ${ }^{12} \mathrm{C}$ and ${ }^{14} \mathrm{~N}$ tend to be preferentially metabolized, so that the body tissues of higher animals including muscle are generally enriched in ${ }^{13} \mathrm{C}$ and ${ }^{15} \mathrm{~N}$ relative to their diets. These isotopic discriminations provide a useful approach for estimating prey-predator relationships.

During the last several decades, the analysis of grazing food chains has been a topic greatly advanced by the analysis of stable carbon and nitrogen isotopes (e.g., Peterson and Fry 1987; Wada and Yoshioka 1995; Tayasu et al. 1997; Fry 2006). As theoretically expected, diet-controlled experiments have clearly demonstrated that a predator is markedly enriched in both ${ }^{13} \mathrm{C}$ and ${ }^{15} \mathrm{~N}$ relative to its prey (DeNiro and Epstein 1978, 1981; Minagawa and Wada 1984). The principles are generalized in the following equations:

$$
\begin{aligned}
& \delta^{13} \mathrm{C}_{\mathrm{TP}=\mathrm{n}}={ }^{13} \Delta(n-1)+\delta^{13} \mathrm{C}_{\mathrm{TP}=1} \\
& \delta^{15} \mathrm{~N}_{\mathrm{TP}=\mathrm{n}}={ }^{15} \Delta(n-1)+\delta^{15} \mathrm{~N}_{\mathrm{TP}=1}
\end{aligned}
$$

where TP represents the trophic position, and $\mathrm{TP}=1,2$, and 3 correspond to the trophic positions of plants, i.e., autotrophs, herbivores, and primary carnivores, respectively. The terms ${ }^{13} \Delta$ and ${ }^{15} \Delta$ are the magnitudes of the trophic enrichment for ${ }^{13} \mathrm{C}$ and ${ }^{15} \mathrm{~N}$, respectively. A number of studies have demonstrated that ${ }^{13} \Delta$ generally ranges from $0 \%$ to $1.5 \%$ with a mean value of $0.8 \%$, whereas ${ }^{15} \Delta$ ranges from $0.5 \%$ and $5.5 \%$ with a mean value of $3.4 \%$ (McConnaughey and McRoy 1979; Fry and Sherr 1984; Rau et al. 1983; Post 2002; Vander Zanden and Rasmussen 2001). Empirically, the ${ }^{13} \Delta$ value tends to be smaller in lakes and coastal oceans than in the pelagic ocean (Fry and Sherr 1984; Post 2002; Wada et al. 1987, 1993).

The diversity in the isotopic compositions of autotrophs is integrated and averaged by herbivorous and carnivorous processes. Most heterotrophs forage over wide areas and depths within varying environments. For example, zooplankton such as the copepod is known to migrate by day and night in the photic zone to feed. This migration of heterotrophs must homogenize the isotopic signatures in time and space.

Why and how do predators become enriched in heavy isotopes? Because amino acids in the form of proteins are the major analytes investigated in food web studies, they are logically the key compounds with which to answer this question. Among the processes that catabolize amino acids, enzymatic decarboxylation and deamination potentially induce the isotopic fractionation of carbon and nitrogen, respectively (O'Leary 1977; Abell and O'Leary 1988). These enzymatic reactions are multistep 
a)

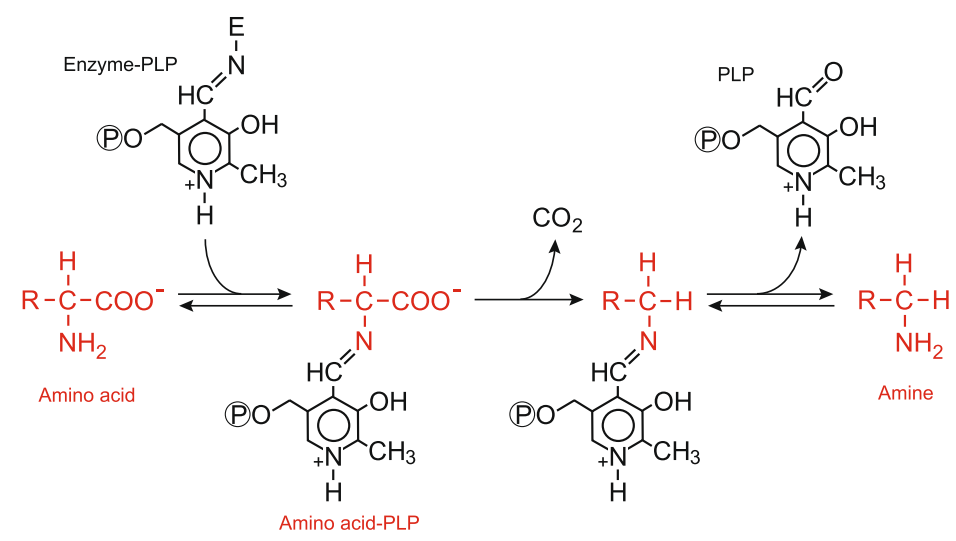

b)

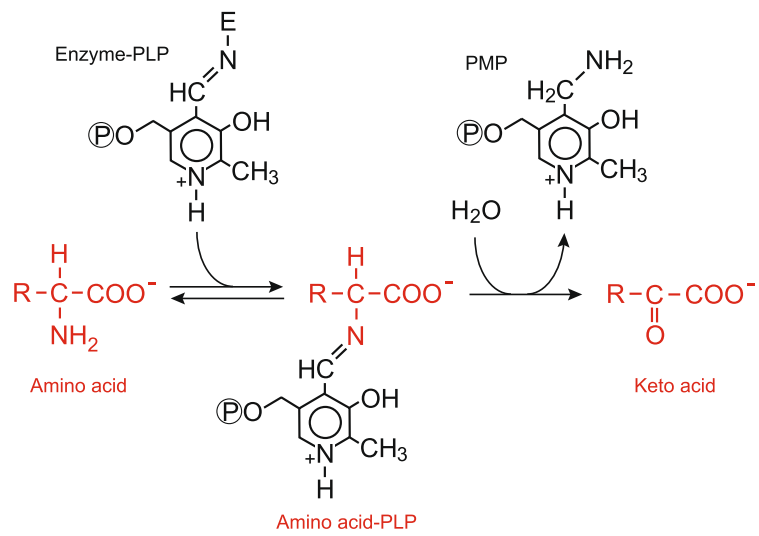

Figure 7 Chemical schemes of the biologically mediated (a) decarboxylation and (b) deamination of amino acids.

processes (Figure 7). In both enzymatic decarboxylation and deamination, the amino acid is first bound to the enzyme pyridoxal phosphate (PLP, a derivative of vita$\min B_{6}$ ) to form amino acid-PLP (Figure 7). Simply put, after the substrate combines with the enzyme, $\mathrm{CO}_{2}$ or $\mathrm{NH}_{3}$ drops off. The first step (formation of the amino acid-enzyme complex) is reversible, whereas the second step is irreversible. Therefore, the magnitude of the isotopic fractionations associated with enzymatic decarboxylation and deamination is dynamically controlled. The carbon isotopic fractionation that occurs during the in vitro decarboxylation of glutamic acid varies between 1.014 and 1.022 (at $37^{\circ} \mathrm{C}, 3.6 \leq p \mathrm{H} \leq 5.5$; O'Leary 1977). The small apparent carbon isotopic fractionation associated with decarboxylation in vivo ( $0.8 \%$ on average) suggests that the first reversible step (e.g., the supply rate of amino acids) may be a major limiting factor in this process.

The in vivo isotopic fractionation associated with the deamination of amino acids has been investigated more extensively than the isotopic fractionation associated with their decarboxylation (e.g., Chikaraishi et al. 2007). During these metabolic processes, most amino acids display strong (2.1\%o to $8.0 \%$ ) ${ }^{15} \mathrm{~N}$-enrichment. In contrast, phenylalanine and methionine display little ${ }^{15} \mathrm{~N}$-enrichment (Macko and Estep 1984; Chikaraishi et al. 2007). We have ascribed this difference in ${ }^{15} \mathrm{~N}$-enrichment between the two groups of amino acids to differences in their metabolic routes (Ohkouchi and Takano 2014). In the first step of metabolism, most amino acids are deaminated to form the corresponding keto acids. However, neither phenylalanine nor methionine is deaminated; instead, phenylalanine forms tyrosine by hydration and methionine forms $\mathrm{S}$-adenosylmethionine by reacting with ATP. This evidence and theoretical considerations confirm that deamination (cleavage of the $\alpha$-carbon-nitrogen bond) is responsible for the ${ }^{15} \mathrm{~N}$-enrichment in bulk organisms along trophic steps. The variation in ${ }^{15} \Delta$ may also be partly ascribed to differences in the amino acid compositions of organisms.

Lake Baikal, located in southern Siberia, is one of the aquatic environments in which this method has been most successfully applied (Yoshii et al. 1999; Wada 2009; Ogawa 1999). The structure of its grazing food 
chain has been extensively studied with field observations and is suggested to be composed of five major ecological groups: phytoplankton, mesozooplankton, macrozooplanktonic amphipods, fish, and seals. Because the ecological diversity is low and the dietary options for each species are consequently limited, the food chain in this pelagic lake is clearly demonstrated in the $\delta^{13} \mathrm{C}-\delta^{15} \mathrm{~N}$ diagram shown in Figure 8 (modified from Yoshii et al. 1999). The $\delta^{13} \mathrm{C}$ values for these organisms are similar to those in pelagic phytoplankton $(-27 \%$ to $-25 \%$ ), suggesting that neither coastal phytoplankton nor terrestrial organic matter is an important carbon source (or energy source) for the pelagic food web. From the phytoplankton at the base of the food chain to the seals as the top predator, these organisms show a clear trend in stepwise ${ }^{15} \mathrm{~N}$-enrichment, beautifully demonstrating the simple prey-predator relationships in this ecosystem.

Another case study introduced here was undertaken in Lake Biwa, the watershed of which has a human population density much higher than that of Lake Baikal. We have been particularly interested in this industrialized and urbanized watershed because it displays significant eutrophication as a consequence of elevated nutrient loading (e.g., Tezuka 1992; Nakanishi and Sekino 1996). Figure 9 summarizes the isotopic compositions of various organisms collected from Lake Biwa in the 1990s (Yamada et al. 1998). The $\delta^{15} \mathrm{~N}-\delta^{13} \mathrm{C}$ diagram not only provides information about the grazing food chain, but also a diagnosis of the effects of human activity on the watershed. The nitrogen supplied from the surrounding mountains to the lake (approximately $0 \%$ ) is substantially depleted in ${ }^{15} \mathrm{~N}$ relative to the phytoplankton (Wada and Hattori 1991; Wada et al. 1998),

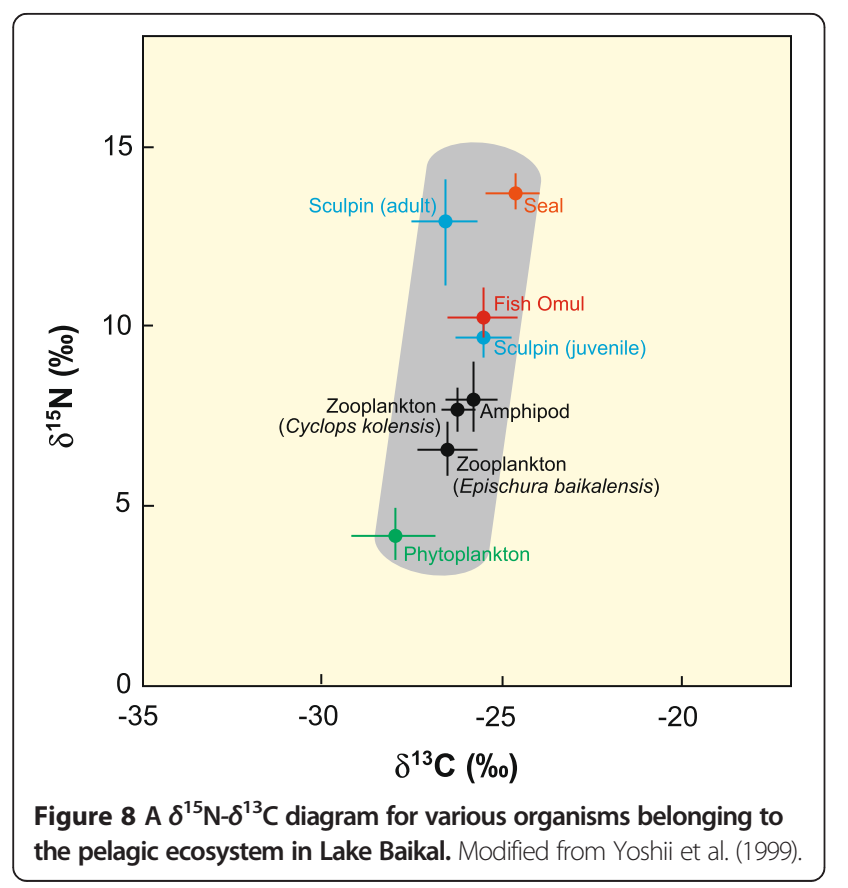

suggesting the presence of either a source(s) or a process (es) that causes ${ }^{15} \mathrm{~N}$ enrichment. A heavy loading of domestic sewage substantially disturbed the natural nitrogen cycle in both the lake and the watershed. In particular, it induced denitrification, leading to the enrichment of ${ }^{15} \mathrm{~N}$ in the nitrogen pool of the lake (Miyajima 1994; Ogawa et al. 2001; A. Makabe and K. Koba, personal communication). A recent microbiological study found abundant denitrifying methane-oxidizing bacteria in the surface layer of the sediment, supporting this view (Kojima et al. 2012). Isotopic analyses of sediment cores and formalin-fixed fish archives revealed that the denitrification was enhanced from the early 1960 s to the 1980s, the period of severe nutrient loading in the lake (Ogawa et al. 2001, 2013).

The accumulation of such case studies over decades has provided great insight into the isotopic signatures of carbon and nitrogen. Except for lagoons and sea-grass meadows, where no or little carbon isotopic fractionation has been observed (i.e., ${ }^{13} \Delta \simeq 0$; Fry and Sherr 1984; Wada et al. 1993), linear relationships have often been observed between ${ }^{13} \mathrm{C}$ - and ${ }^{15} \mathrm{~N}$-enrichment factors. In the cases of Lake Baikal and Lake Biwa shown in Figures 8 and 9, respectively, the slopes of the plots in the $\delta^{13} \mathrm{C}-\delta^{15} \mathrm{~N}$ diagrams were calculated to be $c a .2 .1$ and 1.5, respectively, using analysis of covariance (Wada et al. 2013). In many ecosystems, the magnitudes of ${ }^{13} \mathrm{C}$ - and ${ }^{15} \mathrm{~N}$-enrichment at each trophic step are cross-linked with the following equations (Aita et al. 2011; Wada et al. 2013):

$$
\begin{aligned}
& \text { Terrestrial: } \quad{ }^{15} \Delta /{ }^{13} \Delta=1.61 \pm 0.41 \\
& \text { Marine: } \quad{ }^{15} \Delta /{ }^{13} \Delta=1.24 \pm 0.24
\end{aligned}
$$

Such empirical relationships may be explained from a kinetic perspective. The ${ }^{15} \Delta /{ }^{13} \Delta$ ratio will be constant if the limiting steps in the intrinsic metabolic processes have adapted to the external substrate conditions, whereas the ratio will vary if the balance between the available nitrogen and carbon varies. The relationships between ${ }^{15} \Delta$ and ${ }^{13} \Delta$ can also be interpreted from a physiological perspective. Primarily, the equations should reflect the well-regulated dynamics between enzymatic decarboxylation and deamination, the key processes involved in isotopic enrichment (i.e., ${ }^{15} \Delta$ and ${ }^{13} \Delta$ ) and shared by the whole biota. In the cell, deamination mainly occurs in amino acids, whereas decarboxylation occurs not only in amino acids but in various carboxylic acids including citric acid and oxalic acid, which are intermediates of the citric acid cycle, and in fatty acids, the components of membranes and energy storage materials. The differences in the compound groups subjected to deamination and decarboxylation potentially produces the variations observed in the balance between the ${ }^{13} \mathrm{C}$ and ${ }^{15} \mathrm{~N}$ distributions among heterotrophs. 


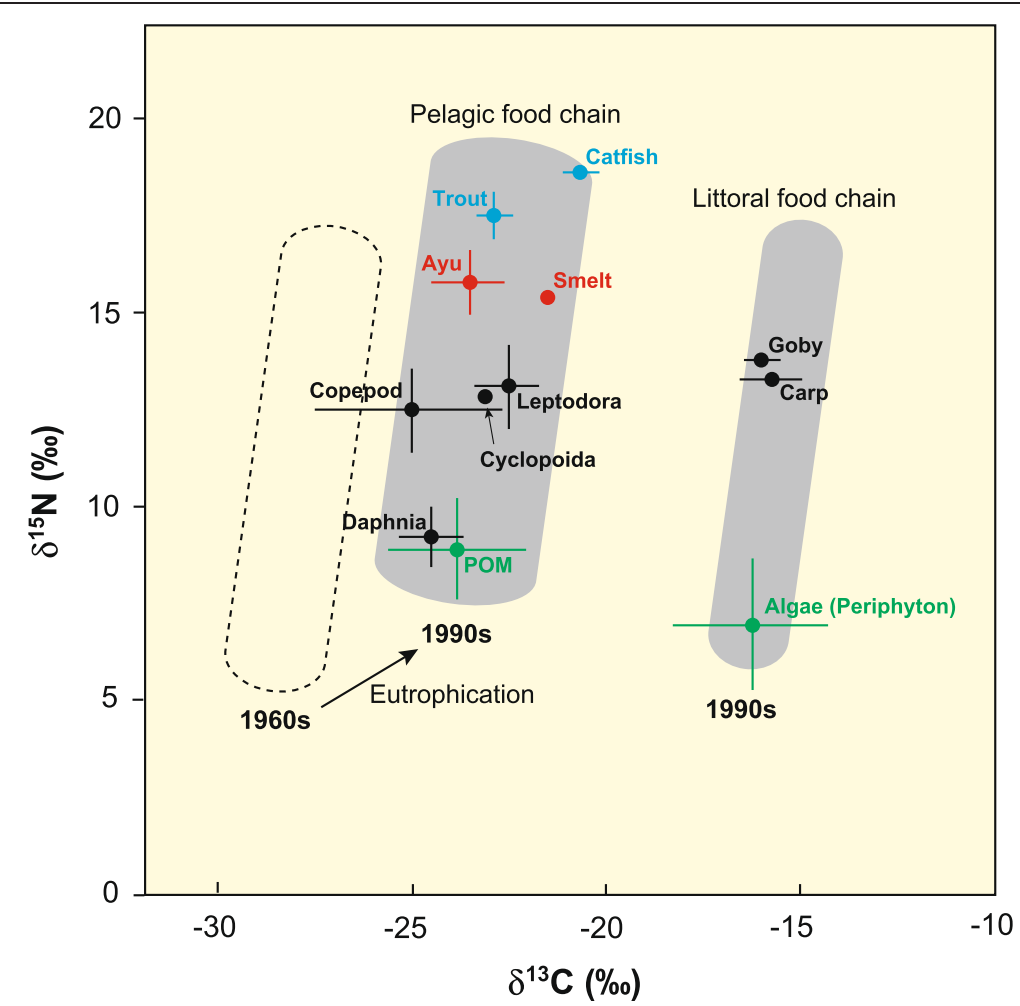

Figure $9 \mathrm{~A} \delta^{15} \mathrm{~N}-\delta^{13} \mathrm{C}$ diagram for the ecosystem in Lake Biwa. Both pelagic and littoral food chains are shown. The estimated isotopic range of Lake Biwa before substantial eutrophication (ca. 1960s to 1980s) is shown as the area surrounded by a broken line. POM, particulate organic matter. Colors indicate the food web groups estimated by Yamada et al. (1998): green, primary producers; black, primary consumers; red, secondary consumers; blue, tertiary consumers. Modified from Yamada et al. (1998) and Wada (2009).

\section{Food chain analysis based on the nitrogen isotopic compositions of amino acids}

The analysis of the nitrogen isotopic compositions of individual amino acids has recently emerged as a tool in food web studies. The nitrogen in an organism is predominantly contained in proteins (i.e., mixtures of amino acids), and as a logical consequence, individual amino acids can provide more accurate information on preypredator relationships than the bulk isotopic method described above.

Careful observation both in the field and in the laboratory has shown that predators are enriched in ${ }^{15} \mathrm{~N}$ to various extents in most amino acids including alanine, valine, and glutamate (a mixture of glutamine and glutamic acid). In contrast, phenylalanine and methionine from predators are only slightly enriched in ${ }^{15} \mathrm{~N}$ relative to their prey (McClelland and Montoya 2002; Chikaraishi et al. 2007). The former group of amino acids is often referred to as 'trophic amino acids' and the latter as 'source amino acids.' Enzymatic deamination (i.e., cleavage of the covalent $\alpha$-carbon-nitrogen bond) to form the corresponding keto acid is the dominant metabolic route for the trophic amino acids. This biochemical reaction is responsible for fractionating the isotopes of nitrogen bonded to the $\alpha$-carbon (Macko et al. 1986; Chikaraishi et al. 2007). In contrast, phenylalanine and methionine, which display little ${ }^{15} \mathrm{~N}$-enrichment, are metabolized to tyrosine and $\mathrm{S}$-adenosylmethionine, respectively, during which the $\alpha$-carbon-nitrogen bond is not cleaved. If the ${ }^{15} \mathrm{~N}$-enrichment factors for most amino acids were reasonably constant among various organisms, it would indicate a well-controlled common reaction network in terms of amino acid metabolism over a wide range of organisms. Because both phenylalanine and methionine are indispensable (essential) amino acids, the nitrogen isotopic compositions of these amino acids in any heterotroph are inherited from autotrophs, the ultimate nitrogen source in the food chain. Consequently, the nitrogen isotopic difference between the source and the trophic amino acids is a first-order function of the trophic position of a given organism in the food web. The balanced nature of amino acids is in strong contrast to the nature of the secondary metabolites (e.g., most lipids, alkaloids, etc.), whose production and degradation are mainly controlled by the physical environment rather than by the physiology of the cell.

Diet-controlled culture experiments in various organisms have shown that the differences in the nitrogen 
isotopic compositions of glutamic acid and phenylalanine are most useful for the accurate quantification of trophic position (Chikaraishi et al. 2009). Trophic position is expressed with an equation in the following form:

$$
[T P]=\left(\delta^{15} \mathrm{~N}_{\mathrm{Glu}}-\delta^{15} \mathrm{~N}_{\text {Phe }}+\beta\right) / 7.6+1
$$

where $\beta$ denotes the isotopic difference between glutamic acid and phenylalanine in autotrophs $([T P]=1)$. The analysis of a number of plants has shown that the mean value of $\beta$ is -3.4 for the aquatic plants with a $1 \sigma$ error of 0.9 (Figure 10a; Chikaraishi et al. 2009). In terrestrial plants, the value of $\beta$ was estimated to be $8.4 \pm$ 1.6 (Figure 10b; Chikaraishi et al. 2011; Steffan et al. 2013). The difference in the $\beta$ values of aquatic and terrestrial plants may be attributable to the differences in their metabolism of phenylalanine. In terrestrial plants, a significant fraction of phenylalanine is metabolized for the synthesis of lignin phenol, making it a branching point in the metabolic pathway (Ohkouchi and Takano 2014). The advantage of amino acid isotopes over bulk isotopes for reconstructing food chains is twofold. First, the isotopic composition of the autotroph $([T P]=1)$ is not required to estimate the trophic position. Second, the error in the estimated trophic position can be minimized.

With this approach, we reexamined the pelagic ecosystem of Lake Baikal (Figure 11). The results confirmed not only the simple food chain but also revealed new aspects of it. The estimated trophic position of the zooplankton Episula baikalensis collected in different years was distributed in a narrow range from 1.9 to 2.1, confirming it as an herbivore rather than an omnivore. The seals were in the highest trophic position with an average value of 5.1. These results basically confirm those of the bulk isotope data described in the previous "Food chain analysis with bulk isotopic compositions: isotopic changes during catabolism" section (Figure 8). However, an important aspect is newly revealed. The trophic length of this food web estimated with the amino acid method is approximately 1 unit longer than that estimated with the bulk method (Yoshii et al. 1999). Assuming that the amino acid method provides the correct information, the ${ }^{15} \Delta$ value in Lake Baikal was recalculated to be approximately $2.5 \%$ rather than $3.3 \%$. The mean trophic position of the endemic fish omul (Coregonus migratorius) was 3.6 rather than 3.0, suggesting that it feeds not only on herbivorous zooplankton but also on carnivores or omnivores. Sculpin, whose mean trophic position was 4.3, may be the bridge between the omul (and probably other fish species with similar trophic positions) and the seal. This view is consistent with the bulk isotope results, which showed approximately 3\%o enrichment in ${ }^{15} \mathrm{~N}$ for the adult sculpin relative to the omul (Figure 8). However, these conclusions are inconsistent with the microscopic observation of the sculpin's stomach contents, which included few fish fragments (Miyasaka et al. 2006). A confident solution has yet to be reached, but the 'snapshot effect' of the stomach contents might explain the inconsistency among the other two approaches.

\section{a) Aquatic food chain}

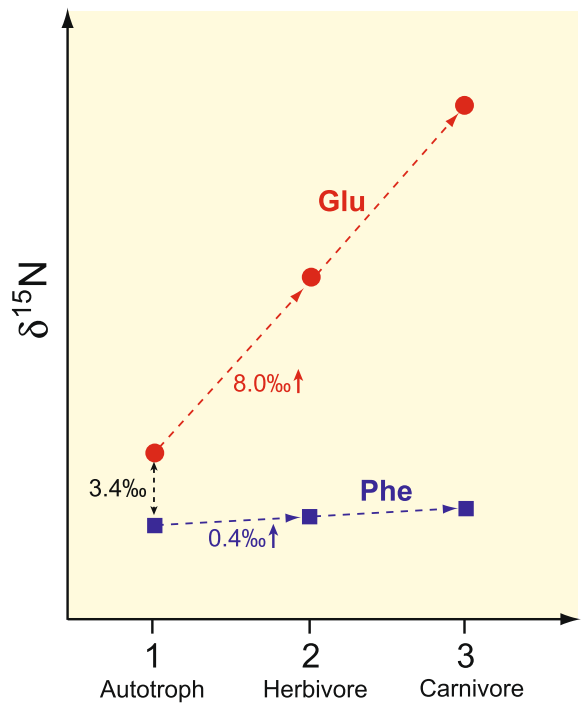

Trophic position

\section{b) Terrestrial food chain}

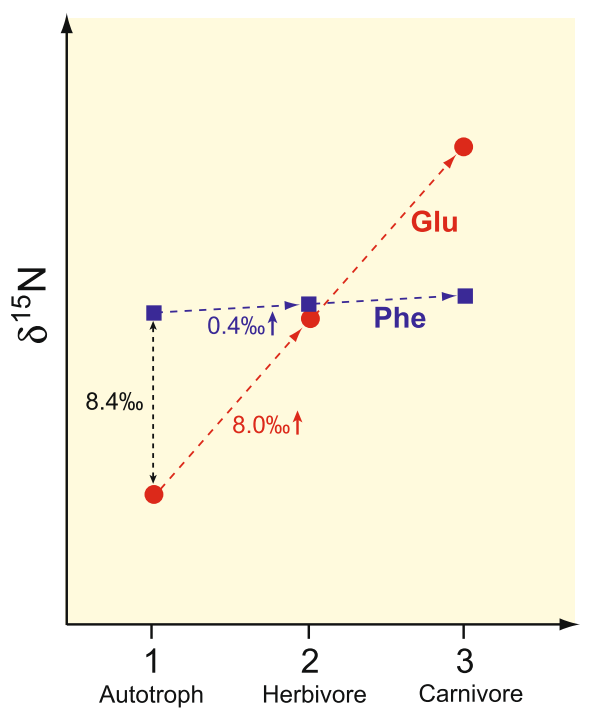

Trophic position

Figure $10 \mathrm{~A}$ schematic diagram showing the relationship between trophic level and $\delta^{15} \mathrm{~N}$ values of amino acids. Relationships between trophic positions and nitrogen isotopic compositions of phenylalanine and glutamate in (a) aquatic and (b) terrestrial $C_{3}$ and $C_{4}$ plants. Vertical axis indicates the relative $\delta^{15} \mathrm{~N}$ values of the amino acids. The mathematical formula for these relationships are given in the text as equation 17. 


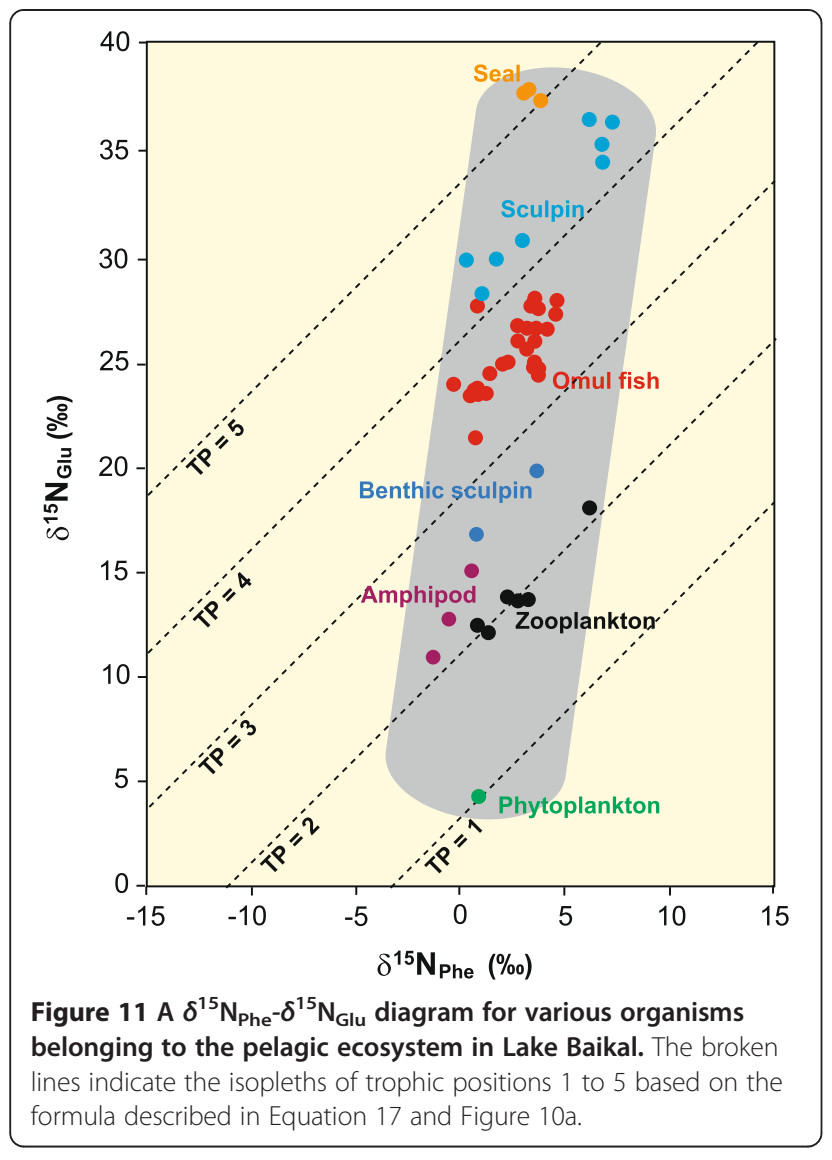

The amino acid method has been used to analyze not only ecological samples but also samples from related fields including anthropology, paleontology, and oceanography to investigate issues related to diet (e.g., Naito et al. 2010; Kashiyama et al. 2010; Popp et al. 2007; Miller et al. 2012; Ohkouchi et al. 2013). The nitrogen in the amino group of amino acids forms the peptide backbone $(-\mathrm{C}-\mathrm{N}-\mathrm{C}-\mathrm{C}-\mathrm{N}-\mathrm{C}-)_{\mathrm{n}}$, so it is not readily exchangeable with ambient nitrogen (e.g., $\mathrm{NH}_{4}{ }^{+}$) unless it is hydrolyzed (Ohkouchi and Takano 2014). Consequently, the nitrogen isotopic signatures of the $\alpha$-amino groups of amino acids are potentially preserved for a long time. Bone collagen and proteins encrusted in carbonate shell are the two major examples of situations in which this preservation occurs. Analysis of the bone collagen of ancient humans (approximately 5,000 years BP) from several archaeological sites in Japan has clearly demonstrated that this method is useful for reconstructing the diets of our ancestors (Naito et al. 2010, 2013). However, it must be kept in mind that the amino acid method provides information only on the protein source and not on the total diet. The carbon isotopic compositions of individual amino acids potentially offer a different perspective on food chains and more insight into ${ }^{13} \Delta$ values (e.g., Macko et al. 1987; Minagawa et al. 1992; McCarthy et al. 2004; Choy and Richards 2009; McMahon et al. 2011; Larsen et al. 2013). This perspective includes not only the sources of diets (e.g., terrestrial vs. aquatic, $\mathrm{C}_{3}$ plants vs. $\mathrm{C}_{4}$ plants), but also the dynamics of amino acids in the cell and during diagenesis.

\section{Isotopic variations in animal organs and the compartmentalization effect}

Higher animals are compartmentalized systems in which numbers of organs work together systematically to perform metabolic activities. Not surprisingly, individual organs and tissues from a single organism have distinctive isotopic signatures (DeNiro and Epstein 1978, 1981; Mizutani et al. 1991). In higher animals such as humans, the isotopic composition of the hair or nails has proven useful in dietary analyses e.g., (Hare et al. 1991; O'Connell et al. 2001; Petzke et al. 2005). Here, we summarize the available information on the distinctive isotopic signatures of individual organs and tissues from a single organism.

The isotopic compositions of the individual organs and tissues of the salmon, globefish, cormorant, Mongolian sheep, rat, and three primates are illustrated in Figure 12 as deviations from those of muscle. In animals such as the rat, salmon, globefish, and Japanese macaque, the brain is enriched in ${ }^{15} \mathrm{~N}$ and depleted in ${ }^{13} \mathrm{C}$ relative to most other organs and tissues (DeNiro and Epstein 1981). In contrast, the cormorant brain is substantially depleted in ${ }^{15} \mathrm{~N}$ (Mizutani et al. 1991). However, this dataset is still limited, and some organs appear to show isotopic signatures inconsistent with those of similar organisms. For example, the liver of the salmon displays a similar $\delta^{15} \mathrm{~N}$ value to that of muscle, whereas the livers of the globefish and rainbow trout are approximately $1 \%$ depleted in ${ }^{15} \mathrm{~N}$ relative to their muscle (Pinneger and Polunin 1999). Isotopic variations of a few permil among organs may be explained by the differences in the turnover rates of proteins. As explained in the last section, the carbon and nitrogen isotopic compositions vary quite markedly, even among the 20 essential amino acids. In an organism with $[T P]=4$, for example, glutamic acid is over $25 \%$ enriched in ${ }^{15} \mathrm{~N}$ relative to phenylalanine. The heterogeneous distribution of amino acids with distinctive isotopic compositions may partly explain the isotopic heterogeneity among organs.

In the guinea pig, the turnover times for carbon and nitrogen in the liver are several months because of the regular mitosis of hepatocytes, whereas the turnover of carbon and nitrogen is much slower in the cerebellum than in the liver. The isotopic signatures of cerebellar DNA acquired in utero are retained for at least the first 6 months of life (Strable et al. 2011). It has also been demonstrated that the neuronal DNA in the human cerebellum turns over little after maturity (Slatkin et al. 1985). This slowness or absence of protein turnover in the brain could explain why its isotopic signatures differ 


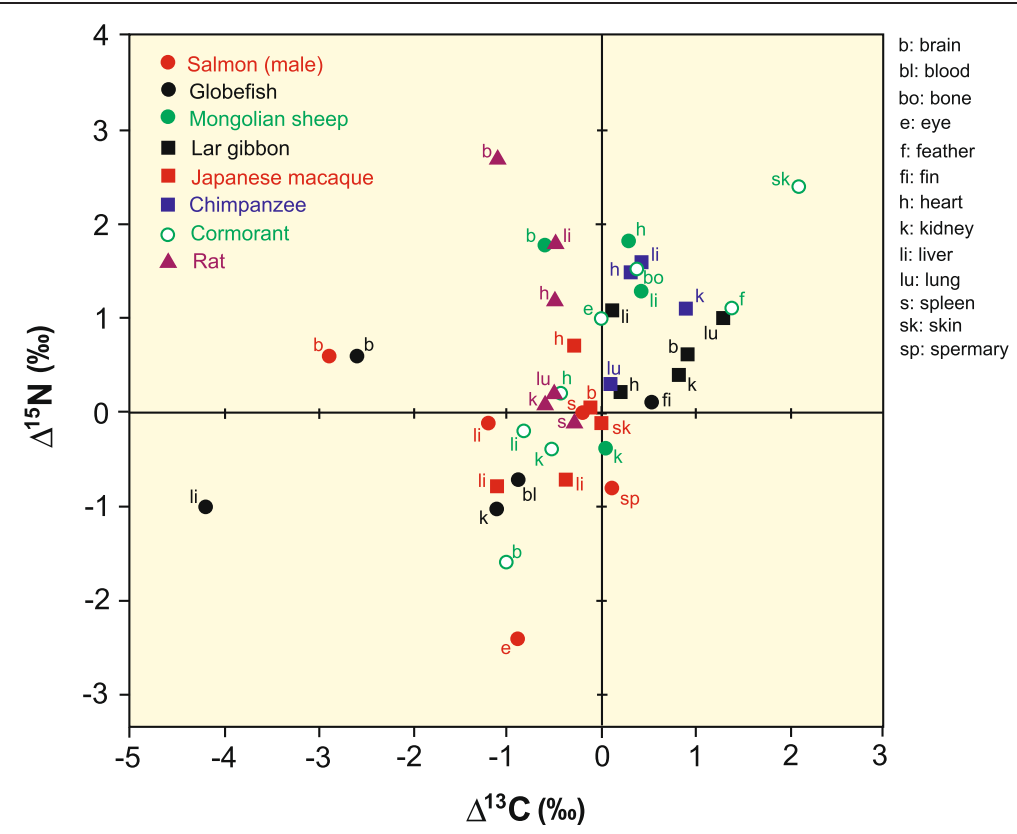

Figure 12 Carbon and nitrogen isotopic compositions of individual organs from various animal samples. These are shown as differences relative to the isotopic composition of muscle (i.e., $\Delta^{13} \mathrm{C}=\delta^{13} \mathrm{C}_{\text {tissue }}-\delta^{13} \mathrm{C}_{\text {muscle, }}$ and $\Delta^{15} \mathrm{~N}=\delta^{15} \mathrm{~N}_{\text {tissue }}-\delta^{15} \mathrm{~N}_{\text {muscle }}$ ). The letters next to the symbols are abbreviations of the organs or tissues. All institutional and national guidelines for the care and use of laboratory animals were followed.

from those of other organs with normal cellular turnover. If tissues are not metabolized, their isotopic signatures should be fixed at the point of production or equilibrated with the chemical substances around them. It is still too early to draw a clear picture, but the compartmentalization effect complicates the isotopic signatures of higher animals. Such isotopic variations potentially confound the interpretation of isotopic signatures, and caution is required when construing them, especially when the bulk isotopic method is applied to higher animals.

\section{Conclusions}

Here, we have reviewed the rules for and the theoretical background of the isotopic approach to environmental and ecological problems and have described the principles regulating the distribution of isotopes in the biosphere, which is inhabited by millions of species. Although we still have limited evidence, we stress that this approach relies strongly on the biochemical and physiological processes common to the whole biota. Even during biochemical reactions, isotopic fractionation originates solely from the physicochemical properties of molecules, the differences in molecular motion. Generalities can be drawn from comprehensive enzymatic processes with equivalent thermodynamic properties in the animal community. Therefore, a deep understanding of the isotopic fractionation that occurs through metabolic pathways is crucial to extend our knowledge of the physiological ecology of animals. Compound-specific isotopic analysis is an effective tool for this purpose.

In this review, we have focused on the grazing food chain, but clarifying the detritus food chain, the other side of the energy flow in ecosystems is essential for understanding the surface environment of this planet. Fragmentary evidence has suggested that compound-specific isotopic analysis is also effective in analyzing the detritus food chain (Macko and Estep 1984; Kohzu et al. 1999; Yamaguchi, 2012; Maki et al. 2014). If true, this approach will demonstrate our 'isotopically ordered world' even more vividly.

\section{Competing interests}

The authors declare that they have no competing interests.

\section{Authors' contributions}

$\mathrm{NO}$ and EW proposed the topic and conceived and designed the study. NOO, YC, and HT carried out the experimental study. All authors have read and approved the final manuscript.

\section{Acknowledgements}

We thank our many colleagues and collaborators who have supported our research for many years. They include the scientists at the Mitsubishi-Kasei Institute of Life Sciences, students and colleagues at the Center for Ecological Research, Kyoto University, and the members of the Department of Biogeochemistry, JAMSTEC. We are especially grateful to Y. Takano, I. Tayasu, T. Nakano, T. Nagata, A. Kohzu, K. Koba, N. Ohte, F. Hyodo, N. Ishikawa, Y. Yamada, S. Steffan, Y. Naito, and C. Yoshikawa for their informal discussions of this topic, Y. Kudo for supplying rat organs and for discussions, and Y. Kabaya, H. Suga, and N. Nishizawa for supporting the laboratory work. We also thank two anonymous reviewers for their comments. This work was partly conducted as a cooperative research program of the Primate Research Institute, Kyoto University, and the Japan Monkey Centre. 


\section{Author details}

${ }^{1} J a p a n$ Agency for Marine-Earth Science and Technology, 2-15 Natsushima-cho, Yokosuka 237-0061, Japan. ²Primate Research Institute, Kyoto University, Inuyama 484-8506, Japan. ${ }^{3}$ National Research Institute of Fisheries Science, 2-12-4 Fukuura Kanazawa-ku, Yokohama 236-8648, Japan.

Received: 15 October 2014 Accepted: 7 January 2015 Published online: 03 February 2015

\section{References}

Abell LM, O'Leary MH (1988) Nitrogen isotope effects on glutamate decarboxylase from Escherichia coli. Biochemistry 27:3325-3330

Aita MN, Tadokoro K, Ogawa NO, Hyodo F, Ishii R, Smith SL, Kishi MJ, Saino T, Saitoh S, Wada E (2011) Linear relationship between carbon and nitrogen isotope ratios along simple food chains in marine environment. J Plankton Res 33:1629-1642

Beale SI (1995) Biosynthesis and structures of porphyrins and hemes. In: Blankenship RE et al (eds) Anoxygenic photosynthetic bacteria. Kluwer, Netherlands

Begon M, Townsend CR, Harper JL (2006) Ecology: from individuals to ecosystems, 4th edn. Blackwell, Malden

Bigeleisen J (1949) The relative reaction velocities of isotopic molecules. J Chem Phys 17:675-678

Chikaraishi $\mathrm{Y}(2014){ }^{13} \mathrm{C} /{ }^{12} \mathrm{C}$ signatures in plants and algae. In: Falkowski PG, Freeman $\mathrm{KH}$ (eds) Treatise on geochemistry, 2nd edn. Elsevier, Amsterdam

Chikaraishi Y, Naraoka H (2003) Compound-specific $\delta D-\delta{ }^{13} \mathrm{C}$ of $n$-alkanes extracted from terrestrial and aquatic plants. Phytochemistry 63:361-371

Chikaraishi Y, Matsumoto K, Ogawa NO, Suga H, Kitazato H, Ohkouchi N (2005) Hydrogen, carbon and nitrogen isotopic fractionations during chlorophyll biosynthesis in C3 higher plants. Phytochemistry 66:911-920

Chikaraishi Y, Kashiyama Y, Ogawa NO, Kitazato H, Ohkouchi N (2007) Metabolic control of nitrogen isotope composition of amino acids in macroalgae and gastropods: implications for aquatic food web studies. Mar Ecol Prog Ser 342:85-90

Chikaraishi Y, Ogawa NO, Kashiyama Y, Takano Y, Suga H, Tomitani A, Miyashita H, Kitazato H, Ohkouchi N (2009) Determination of aquatic food-web structure based on compound-specific nitrogen isotopic composition of amino acids. Limnol Oceanogr Meth 7:740-750

Chikaraishi Y, Ogawa NO, Ohkouchi N (2010) Further evaluation of the trophic level estimation based on nitrogen isotopic composition of amino acids. In: Ohkouchi N et al (eds) Earth, life, and isotopes. Kyoto University Press, Kyoto

Chikaraishi Y, Ogawa NO, Doi H, Ohkouchi N (2011) ${ }^{15} \mathrm{~N} /{ }^{14} \mathrm{~N}$ ratios of amino acids as a tool for studying terrestrial food webs: a case study of terrestrial insects (bees, wasps, and hornets). Ecol Res 26:835-844

Choy K, Richards MP (2009) Stable isotope evidence of human diet at the Nukdo shell midden site, South Korea. J Archaeol Sci 36:1312-1318

Coplen TB, Böhlke JK, De Bièvre P, Ding T, Holden NE, Hopple J, Krouse HR, Lamberty A, Peiser HS, Révész K, Rieder SE, Rosman KJR, Roth E, Taylor PDP, Vocke RDJ, Xian YK (2002) Isotope-abundance variations of selected elements. Pure Appl Chem 74:1987-2017

Craig H (1953) The geochemistry of the stable carbon isotopes. Geochim Cosmochim Acta 3:53-92

Craig H (1957) Isotopic standards for carbon and oxygen and correction factors for mass-spectrometric analysis of carbon dioxide. Geochim Cosmochim Acta $12: 133-149$

Cunz M (2011) Carbon cycle: a dent in carbon's gold standard. Nature 477:547-548

DeNiro MJ, Epstein S (1977) Mechanism of carbon isotope fractionation associated with lipid synthesis. Science 197:261-263

DeNiro MJ, Epstein S (1978) Influence of diet on the distribution of carbon isotopes in animals. Geochim Cosmochim Acta 42:495-506

DeNiro MJ, Epstein S (1981) Influence of diet on the distribution of nitrogen isotopes in animals. Geochim Cosmochim Acta 45:341-351

Falkowski PG (1975) Nitrate uptake in marine phytoplankton: (nitrate, chloride)activated adenosine triphosphatase from Skeletonema costatum (Bacillariophyceae). J Phycol 11:323-326

Farquhar GD (1983) On the nature of carbon isotope discrimination in $C_{4}$ species. Aust J Plant Physiol 10:205-226

Farquhar GD, O'Leary MH, Berry JA (1982) On the relationship between carbon isotope discrimination and the intercellular carbon dioxide concentration in leaves. Aust J Plant Physiol 9:121-137
Fogel ML, Cifuentes LA (1993) Isotope fractionation during primary production. In: Engel MH, Macko SA (eds) Organic Geochemistry: Principles and Applications. Plenum, New York

Fry B (2006) Stable isotope ecology. Springer, New York

Fry B, Sherr EB (1984) ${ }^{13} \mathrm{C}$ measurements as indicators of carbon flow in marine and freshwater ecosystems. Contrib Mar Sci 27:13-47

Hare PE, Fogel ML, Stafford TW Jr, Mitchell AD, Hoering TC (1991) The isotopic composition of carbon and nitrogen in individual amino acids isolated from modern and fossil proteins. J Archaeol Sci 18:277-292

Hayes JM (1991) Factors controlling ${ }^{13} \mathrm{C}$ contents of sedimentary organic compounds: principles and evidence. Mar Geol 113:111-125

Hayes JM, Takigiku R, Ocampo R, Callot HJ, Albrecht P (1989) Isotopic compositions and probable origins of organic molecules in the Eocene Messel shale. Nature 329:48-51

Heaton THE (1986) Isotopic studies of nitrogen pollution in the hydrosphere and atmosphere: a review. Chem Geol 59:87-102

Hinrichs KU, Hayes JM, Sylva SP, Brewer PG, DeLong EF (1999) Methaneconsuming archaebacteria in marine sediments. Nature 398:802-805

Hoering TC (1955) Variations of nitrogen-15 abundance in naturally occurring substances. Science 122:1233-1234

Hoering TC, Ford HT (1960) Isotope effect in the fixation of nitrogen by Azotobacter. J Am Chem Soc 82:376-378

Jähne B, Heinz G, Dietrich W (1987) Measurement of the diffusion coefficients of sparingly soluble gases in water. J Geophys Res 92:10767-10776

Junk G, Svec HJ (1958) The absolute abundance of the nitrogen isotopes in the atmosphere and compressed gas from various sources. Geochim Cosmochim Acta 14:234-243

Kashiyama Y, Ogawa NO, Chikaraishi Y, Kashiyama N, Sakai S, Tanabe K, Ohkouchi N (2010) Reconstructing the life history of modern and fossil nautiloids based on the nitrogen isotopic composition of shell organic matter and amino acids. In: Tanabe K et al (eds) Cephalopods: present and past. Tokai University Press, Tokyo

Katase T, Wada E (1990) Isolation of chlorophyll $a$ in Microcystis spp. for determination of stable isotopes of carbon and nitrogen, and variation in Suwa Lake (in Japanese with English abstract). Bunseki Kagaku 39:451-456

Klots CE, Benson BB (1963) Isotope effect in solution of oxygen and nitrogen in distilled water. J Chem Phys 38:890-892

Kohzu A, Yoshioka T, Ando T, Takahashi M, Koba K, Wada E (1999) Natural ${ }^{13} \mathrm{C}$ and ${ }^{15} \mathrm{~N}$ abundance of field-collected fungi and their ecological implications. New Phytol 144:323-330

Kojima H, Tsutsumi M, Ishikawa K, Iwata T, Mumann M, Fukui M (2012) Distribution of putative denitrifying methane oxidizing bacteria in sediment of a freshwater lake, Lake Biwa. Syst Appl Microbiol 35:233-238

Kroopnick PM (1985) The distribution of ${ }^{13} \mathrm{C}$ of $\mathrm{\Sigma CO}_{2}$ in the world oceans. DeepSea Res 32:57-84

Larsen T, Ventura M, Andersen N, O'Brien DM, Piatkowski U, McCarthy MD (2013) Tracing carbon sources through aquatic and terrestrial food webs using amino acid stable isotope fingerprinting. PLoS One 8:e73441, doi:10.1371/ journal.pone.0073441

Macko SA, Estep ML (1984) Microbial alteration of stable nitrogen and carbon isotopic compositions of organic matter. Org Geochem 6:787-790

Macko SA, Fogel Estep ML, Engel MH, Hare PE (1986) Kinetic fractionation of nitrogen isotopes during amino acid transamination. Geochim Cosmochim Acta 50:2143-2146

Macko SA, Fogel Estep ML, Hare PE, Hoering TC (1987) Isotope fractionation of nitrogen and carbon in the synthesis of amino acid by microorganisms. Chem Geol 65:79-92

Maki K, Ohkouchi N, Chikaraishi Y, Fukuda H, Miyajima T, Nagata T (2014) Influences of nitrogen substrates and substrate C:N ratios on the nitrogen isotopic composition of amino acids from the marine bacterium Vibrio harveyi. Geochim Cosmochim Acta 140:521-530

Mariotti A (1983) Atmospheric nitrogen is a reliable standard for natural ${ }^{15} \mathrm{~N}$ abundance measurements. Nature 303:685-687

Mariotti A, German JC, Hubert P, Kaiser P, Letolle R, Tardiex A, Tardiex P (1981) Experimental determination of nitrogen kinetic isotope fractionation: some principles; illustration for the denitrification and nitrification processes. Plant Soil 62:413-430

McCarthy MD, Benner R, Lee C, Hedges Jl, Fogel ML (2004) Amino acid carbon isotopic fractionation patterns in oceanic dissolved organic matter: an unaltered photoautotrophic source for dissolved organic nitrogen in the ocean? Mar Chem 92:123-134 
McClelland JW, Montoya JP (2002) Trophic relationships and the nitrogen isotopic composition of amino acids in plankton. Ecology 83:2173-2180

McConnaughey T, McRoy CP (1979) Food-web structure and the fractionation of carbon isotopes in the Bering Sea. Mar Biol 53:257-262

McMahon KW, Fogel ML, Johnson BJ, Houghton LA, Thorrold SR (2011) A new method to reconstruct fish diet and movement patterns from $\delta^{13} \mathrm{C}$ values in otolith amino acids. Can J Fish Aq Sci 68:1330-1340

Miller MJ, Chikaraishi Y, Ogawa NO, Yamada Y, Tsukamoto K, Ohkouchi N (2012) A low trophic position of Japanese eel larvae indicates feeding on marine snow. Biol Lett 9:20120826

Minagawa M, Wada E (1984) Stepwise enrichment of ${ }^{15} \mathrm{~N}$ along food chains. Further evidence and the relation between ${ }^{15} \mathrm{~N}$ and animal age. Geochim Cosmochim Acta 48:1135-1140

Minagawa M, Wada E (1986) Nitrogen isotope ratios of red tide organisms in the East China Sea: a characterization of biological nitrogen fixation. Mar Chem 19:245-259

Minagawa M, Egawa S, Kabaya Y, Karasawa-Tsuru K (1992) Carbon and nitrogen isotope analysis for amino acids from biological samples. Mass Spectros 40:47-56

Minagawa M, Ohashi M, Kuramoto T, Noda N (2001) $\delta^{15} \mathrm{~N}$ of PON and nitrate as a clue to the origin and transformation of nitrogen in the subarctic North Pacific and its marginal sea. J Oceanogr 57:285-300

Miyajima T (1994) Mud-water fluxes of inorganic nitrogen and manganese in the pelagic region of Lake Biwa: seasonal dynamics and impact on the hypolimnetic metabolism. Arch Hydrobiol 130:303-324

Miyake $Y$, Wada $E$ (1967) The abundance ratio of ${ }^{15} \mathrm{~N} /{ }^{14} \mathrm{~N}$ in marine environments. Rec Oceanogr Works Jpn 9:37-53

Miyasaka H, Dzyuba YV, Genkai-Kato M, Ito S, Kohzu A, Anoshko PN, Khanayev IV, Shubenkov SG, Melnik NG, Timoshkin OA, Wada E (2006) Feeding ecology of two planktonic sculpins, Comephorus baicalensis and Comephorus dybowskii (Comephoridae), in Lake Baikal. Ichthyol Res 53:419-422

Mizutani H, Kabaya Y, Wada E (1991) Nitrogen and carbon isotope compositions relate linearly in cormorant tissues and its diet. Isotopenpraxis 27:166-168

Mook WG, Bommerson JC, Staverman WH (1974) Carbon isotope fractionation between dissolved bicarbonate and gaseous carbon dioxide. Earth Planet Sci Lett 22:169-176

Naito Y, Honch NV, Chikaraishi Y, Ohkouchi N, Yoneda M (2010) Quantitative evaluation of marine protein contribution in ancient diets based on nitrogen isotope ratios of individual amino acids in bone collagen: an investigation at the Kitakogane Jomon site. Am J Phys Anthropol 143:31-40

Naito Y, Chikaraishi Y, Ohkouchi N, Yoneda M (2013) Evaluation of carnivory in inland Jomon hunter-gatherers based on nitrogen isotope ratios of individual amino acids in bone collagen. J Archaeol Sci 40:2913-2923

Nakajima Y, Okada H, Oguri K, Suga H, Kitazato H, Koizumi Y, Fukui M, Ohkouchi N (2004) Distribution of chloropigments in suspended particulate matter and benthic microbial mat of a meromictic lake, Lake Kaiike, Japan. Environ Microbiol 5:1103-1110

Nakanishi M, Sekino T (1996) Recent drastic changes in Lake Biwa biocommunities, with special attention to exploitation of the littoral zone. Geo J 40:63-67

Nier AO, Gulbransen EA (1939) Variations in the relative abundance of the carbon isotopes. J Am Chem Soc 61:697-698

O'Connell TC, Hedges REM, Healey MA, Simpson AHRW (2001) Isotopic comparison of hair, nail and bone: modern analyses. J Archaeol Sci 28:1247-1255

O'Leary MH (1977) Studies of enzyme reaction mechanisms by means of heavyatom isotope effects. In: Cleland WW, O'Leary MH, Northrop DB (eds) Isotope effects on enzyme-catalyzed reactions. University Park Press, Baltimore

O'Leary MH (1981) Carbon isotope fractionation in plants. Phytochemistry 20:553-567

O'Leary MH (1984) Measurement of the isotope fractionation associated with diffusion of carbon dioxide in aqueous solution. J Phys Chem 88:823-825

Ogawa N (1999) Fluctuations of lacustrine environments during the last several decades revealed from stable isotope ratios of fish specimens. Dissertation, Kyoto University

Ogawa NO, Koitabashi T, Oda H, Nakamura T, Ohkouchi N, Wada E (2001) Fluctuations of nitrogen isotope ratio of gobiid fish specimens and sediments in Lake Biwa during the 20th century. Limnol Oceanogr 46:1228-1236

Ogawa NO, Chikaraishi Y, Ohkouchi N (2013) Trophic position estimates of formalin-fixed samples with nitrogen isotopic compositions of amino acids: an application to gobiid fish (Isaza) in Lake Biwa, Japan. Ecol Res 28:697-702
Ohkouchi N, Takano Y (2014) Organic nitrogen: sources, fates, and chemistry. In: Falkowski PG, Freeman KH (eds) Treatise on geochemistry, 2nd edn. Elsevier Amsterdam

Ohkouchi N, Nakajima Y, Okada H, Ogawa NO, Suga H, Oguri K, Kitazato H (2005) Biogeochemical processes in the meromictic Lake Kaiike: implications from carbon and nitrogen isotopic compositions of photosynthetic pigments. Environ Microbiol 7:1009-1016

Ohkouchi N, Kashiyama Y, Kuroda J, Ogawa NO, Kitazato H (2006) The importance of diazotrophic cyanobacteria as primary producers during cretaceous oceanic anoxic event 2. Biogeosciences 3:467-478

Ohkouchi N, Nakajima Y, Okada H, Ogawa NO, Chikaraishi Y, Suga H, Sakai S, Kitazato H (2008) Carbon isotopic composition of tetrapyrrole nucleus in chloropigments from a saline meromictic lake: a mechanistic view for interpreting the isotopic signature of alkyl porphyrins in geological samples. Org Geochem 39:521-531

Ohkouchi N, Tsuda R, Chikaraishi Y, Tanabe K (2013) A preliminary estimate of the trophic position of the deep-water ram's horn squid Spirula spirula based on the nitrogen isotopic composition of amino acids. Mar Biol 160:773-779

Pagani M, Zachos J, Freeman KH, Bohaty S, Tipple B (2005) Marked decline in atmospheric carbon dioxide concentrations during the Paleogene. Science 309:600-603

Park R, Epstein S (1960) Carbon isotope fractionation during photosynthesis. Geochim Cosmochim Acta 21:110-126

Parwel A, Ryhage R, Wickman FE (1957) Natural variations in the relative abundances of the nitrogen isotopes. Geochim Cosmochim Acta 11:165-170

Peterson BJ, Fry B (1987) Stable isotopes in ecosystem studies. Annu Rev Ecol Syst 18:293-320

Petzke KJ, Boeing H, Klaus S, Metges CC (2005) Carbon and nitrogen stable isotopic composition of hair protein and amino acids can be used as biomarkers for animal-derived dietary protein intake in humans. Nutr Meth 135:1515-1520

Pinneger JK, Polunin NVC (1999) Differential fractionation of $\delta^{13} \mathrm{C}$ and $\delta^{15} \mathrm{~N}$ among fish tissues: implications for the study of trophic interactions. Funct Ecol 13:225-231

Popp BN, Graham BS, Olson RJ, Hannides CCS, Lott MJ, López-lbarra GA, GalvánMagañaF FB (2007) Insight into the trophic ecology of yellowfin tuna, Thunnus albacares, from compound-specific nitrogen isotope analysis of proteinaceous amino acids. In: Dawson T, Siegwolf R (eds) Stable isotopes as indicators of ecological change. Elsevier, Amsterdam

Post DM (2002) Using stable isotopes to estimate trophic position: models, methods, and assumptions. Ecology 83:703-718

Quandt L, Gottschalk G, Ziegler H, Stichler W (1977) Isotope discrimination by photosynthetic bacteria. FEMS Microbiol Lett 1:125-128

Rankama K (1948) New evidence of the origin of pre-Cambrian carbon. Geol Soc Am Bull 59:389-416

Rau GH, Mearns AJ, Young DR, Olson RJ, Schafer HA, Kaplan IR (1983) Animal ${ }^{13} \mathrm{C} /{ }^{12} \mathrm{C}$ correlates with trophic level in pelagic food webs. Ecology 64:1314-1318

Raven JA (1997) Inorganic carbon acquisition by marine autotrophs. Adv Bot Res 27:85-209

Sachs JP, Repeta DJ, Goericke R (1999) Nitrogen and carbon isotopic ratios of chlorophyll from marine phytoplankton. Geochim Cosmochim Acta 63:1431-1441

Sigman DM, Karsh KL, Casciotti KL (2009) Nitrogen isotopes in the ocean. In: Steele $\mathrm{JH}$ et al (eds) Encyclopedia of ocean sciences. Academic, London

Sirevåg R, Buchanan BB, Berry JA, Troughton JH (1977) Mechanisms of $\mathrm{CO}_{2}$ fixation in bacteria photosynthesis studied by the carbon isotope fractionation technique. Arch Microbiol 112:35-38

Slatkin DN, Friedman L, Irsa AP, Micca PL (1985) The stability of DNA in human cerebellar neurons. Science 228:1002-1004

Steffan S, Chikaraishi Y, Horton DR, Ohkouchi N, Singleton ME, Miliczky E, Hogg DB, Jones VP (2013) Trophic hierarchies illuminated via amino acid isotopic analysis. PLoS One 8:e76152, doi:10.1371/journal.pone.0076152

Strable MS, Tshanz CL, Varamini B, Chikaraishi Y, Ohkouchi N, Brenna JT (2011) Mammalian DNA $\delta^{15} \mathrm{~N}$ exhibits $40 \%$ intramolecular variation and is unresponsive to dietary protein level. Rapid Commun Mass Spectrom 25:3555-3562

Takahashi K, Wada E, Sakamoto M (1991) Relationship between carbon isotope discrimination and the specific growth rate of green alga Chlamydomonas reinhardtii. Jpn J Limnol 52:105-112

Takano Y, Chikaraishi Y, Ogawa NO, Nomaki H, Morono Y, Inagaki F, Kitazato H, Hinrichs KU, Ohkouchi N (2010) Sedimentary membrane lipids recycled by deep-sea benthic archaea. Nat Geosci 3:858-861 
Tayasu I, Abe T, Eggleton P, Bignell DE (1997) Nitrogen and carbon isotope ratios in termites: an indicator of trophic habit along the gradient from woodfeeding to soil-feeding. Ecol Entomol 22:343-351

Tayasu I, Hirasawa R, Ogawa NO, Ohkouchi N, Yamada K (2011) New organic reference materials for carbon- and nitrogen-stable isotope ratio measurements provided by Center for Ecological Research, Kyoto University, and Institute of Biogeosciences, Japan Agency for Marine-Earth Science and Technology. Limnology 12:261-266

Tezuka Y (1992) Recent trend in the eutrophication of the north basin of Lake Biwa. Jpn J Limnol 53:139-144

Vander Zanden MJ, Rasmussen JB (2001) Variation in $\delta^{15} \mathrm{~N}$ and $\delta^{13} \mathrm{C}$ trophic fractionation: implications for aquatic food web studies. Limnol Oceanogr 46:2061-2066

Vitòria L, Otero N, Soler A, Canals A (2004) Fertilizer characterization: isotopic data (N, S, O, C, and Sr). Environ Sci Technol 38:3254-3262

Wada E (1980) Nitrogen isotope fractionation and its significance in biogeochemical processes occurring in marine environments. In: Goldberg ED et al (eds) Isotope marine chemistry. Uchida Rokkakudo, Tokyo

Wada $\mathrm{E}$ (2009) Stable $\delta^{15} \mathrm{~N}$ and $\delta^{13} \mathrm{C}$ isotope ratios in aquatic ecosystems. Proc Jpn Acad Ser B 85:98-107

Wada E, Hattori A (1978) Nitrogen isotope effects in assimilation of nitrogenous compounds by marine algae. Geomicrobiol J 1:85-101

Wada E, Hattori A (1991) Nitrogen in the sea: forms, abundances and rate processes. CRC, Boca Raton

Wada E, Yoshioka T (1995) Isotope biogeochemistry of several aquatic ecosystems. Geochem Int 32:121-140

Wada E, Kadonaga T, Matsuo S (1975) ${ }^{15} \mathrm{~N}$ abundance in nitrogen of naturally occurring substances and global assessment of denitrification from isotopic viewpoint. Geochem J 9:139-148

Wada E, Shibata R, Torii T (1981) ${ }^{15} \mathrm{~N}$ abundance in Antarctica: origin of soil nitrogen and ecological implications. Nature 292:327-329

Wada E, Imaizumi R, Kabaya Y, Yasuda T, Kanamori T, Saito G, Nishimune A (1986) Estimation of symbiotically fixed nitrogen in field grown soybeans: an application of natural ${ }^{15} \mathrm{~N} /{ }^{14} \mathrm{~N}$ abundance and a low level ${ }^{15} \mathrm{~N}$-tracer technique. Plant Soil 93:269-286

Wada E, Terazaki M, Kabaya Y, Nemoto T (1987) ${ }^{15} \mathrm{~N}$ and ${ }^{13} \mathrm{C}$ abundances in the Antarctic Ocean with emphasis on the biogeochemical structure of the food web. Deep-Sea Res 34:829-841

Wada E, Kabaya Y, Kurihara Y (1993) Stable isotopic structure in aquatic ecosystem. J Biosci 18:483-499

Wada E, Ando T, Kumazawa K (1995) Biodiversity of stable isotope ratios. In: Wada E et al (eds) Stable isotopes in the biosphere. Kyoto University Press, Kyoto

Wada E, Tayasu I, Koba K, Matsubara T, Ogawa NO, Yamada Y, Yoshii K, Sugimoto A (1998) The use of stable isotopes for ecological studies. In: Pathak B et al (eds) Ecology today: an anthology of contemporary ecological research. International Science, New Delhi

Wada E, Ohki K, Yoshikawa S, Parker PL, Baalen CV, Matsumoto Gl, Aita MN, Saino T (2012) Ecological aspects of carbon and nitrogen isotope ratios of cyanobacteria. Plankton Benthos Res 7:135-145

Wada E, Ishii R, Aita MN, Ogawa NO, Kohzu A, Hyodo F, Yamada Y (2013) Possible ideas on carbon and nitrogen trophic fractionation of food chains: a new aspect of food-chain stable isotope analysis in Lake Biwa, Lake Baikal, and the Mongolian grassland. Ecol Res 28:173-181

Wickman FE (1952) Variations in the relative abundance of the carbon isotopes in plants. Geochim Cosmochim Acta 2:243-254

Yamada Y, Ueda T, Koitabashi T, Wada E (1998) Horizontal and vertical isotopic model of Lake Biwa ecosystem. Jpn J Limnol 59:409-427

Yamaguchi Y (2012) Biogeochemical dynamics of amino acids in marine sediments: constraints from compound-specific nitrogen isotopic composition and $\mathrm{D} / \mathrm{L}$ ratio. Dissertation, University of Tokyo

Yoshii K, Melnik NG, Timoshkin OA, Bondarenko NA, Anoshko PN, Yoshioka T, Wada E (1999) Stable isotope analyses of the pelagic food web in Lake Baikal. Limnol Oceanogr 44:502-511

\section{Submit your manuscript to a SpringerOpen ${ }^{\circ}$ journal and benefit from:}

- Convenient online submission

- Rigorous peer review

- Immediate publication on acceptance

- Open access: articles freely available online

- High visibility within the field

- Retaining the copyright to your article

Submit your next manuscript at $>$ springeropen.com 